Systematic Review

\title{
e Diagnostic Utility of Selective Nerve Root Blocks in the Diagnosis of Lumbosacral Radicular Pain: Systematic Review and Update of Current Evidence
}

\author{
Sukdeb Datta, MD1, Laxmaiah Manchikanti, MD², Frank J.E. Falco, MD², \\ Aaron K. Calodney, MD, Sairam Atluri, MD', Ramsin M. Benyamin, MD', \\ Ricardo Buenaventura, $\mathrm{MD}^{7}$, and Steven P. Cohen, $\mathrm{MD}^{8}$
}

\begin{abstract}
From: 'Laser Spine \& Pain Institute, and Mount Sinai School of Medicine, New York, NY; 'Pain Management Center of Paducah, Paducah, KY, and University of Louisville, Louisville, KY; ${ }^{3}$ Mid Atlantic Spine \& Pain Physicians, Newark, DE, and Temple University Hospital, Philadelphia, PA; ${ }^{4}$ Texas Pain at the Texas Spine and Joint Hospital, Tyler, TX; ${ }_{5}^{5}$ Tri-State Spine Care Institute, Cincinnati, $\mathrm{OH} ;{ }^{6}$ Millennium

Pain Center, Bloomington, IL, and University of Illinois, Urbana-Champaign, IL; ${ }^{7}$ Wright State University School of Medicine, Dayton, $\mathrm{OH}$, and Pain Relief of Dayton, Centerville, OH; and ${ }^{8}$ Johns Hopkins University School of Medicine, Baltimore, MD, Uniformed Services University of the Health Sciences, Bethesda, MD.

Additional author affiliation on P. SE 115

Address correspondence: Laxmaiah Manchikanti, M.D. 2831 Lone Oak Road Paducah, Kentucky 42003

E-mail: drlm@thepainmd.com:
\end{abstract}

Disclaimer: There was no external funding in the preparation of this manuscript. Conflict of interest: None.

Manuscript received: 10/22/2012 Accepted for publication: $12 / 20 / 2012$

Free full manuscript: www.pain physicianjournal.com
Background: Lumbosacral selective nerve root blocks and/ or transforaminal epidural injections are used for diagnosis and treatment of different disorders causing low back and lower extremity pain. A clear consensus on the use of selective nerve root injections as a diagnostic tool does not currently exist. Additionally, the validity of this procedure as a diagnostic tool is not clear.

Objective: To evaluate and update the accuracy of selective nerve root injections in diagnosing lumbar spinal disorders.

Study Design: A systematic review of selective nerve root blocks for the diagnosis of low back and lower extremity pain.

Methods: Methodological quality assessment of included studies was performed using the Quality Appraisal of Reliability Studies (QAREL) checklist. Only diagnostic accuracy studies meeting at least $50 \%$ of the designated inclusion criteria were utilized for analysis. Studies scoring less than $50 \%$ are presented descriptively and analyzed critically.

The level of evidence was classified as good, fair, or limited or poor based on the quality of evidence grading scale developed by the United States Preventive Services Task Force (USPSTF).

Data sources included relevant literature identified through searches of PubMed and EMBASE from 1966 to September 2012, and manual searches of the bibliographies of known primary and review articles.

Outcome Measures: In this review, we evaluated studies in which controlled local anesthetic blocks were performed using at least $50 \%$ pain relief as the reference standard.

Results: There is limited evidence for the accuracy of selective nerve root injections as a diagnostic tool for lumbosacral disorders. There is limited evidence for their use in the preoperative evaluation of patients with negative or inconclusive imaging studies.

Limitations: The limitations of this systematic review include a paucity of literature, variations in technique, and variable criterion standards for the diagnosis of lumbar radicular pain.

Conclusions: There is limited evidence for selective nerve root injections as a diagnostic tool in evaluating low back pain with radicular features. However, their role needs to be further clarified by additional research and consensus.

Key words: Low back pain, lower extremity pain, selective nerve root block, transforaminal epidural injection, discogenic pain, radiculitis, sciatica radiculopathy, nerve root pain

Pain Physician 2013; 16:-SE97-SE124 
umbar discectomy is the most common surgical procedure performed in the United States for patients having back and leg symptoms (1). The up to 15-fold variation in regional discectomy rates in the United States, and dramatically lower rates internationally, raise questions regarding the appropriateness of some of these surgeries $(2,3)$. The Spine Patient Outcomes Research Trial (SPORT) (1), which enrolled patients from 13 multidisciplinary spine clinics in 11 U.S. states from 2000 to 2004 included 501 surgical candidates with radiologically-confirmed lumbar intervertebral disc herniation and persistent signs and symptoms for at least 6 weeks. This study showed significant improvement in all parameters at longterm follow-up. A subgroup analysis of these patients showed a lack of improvement in patients undergoing epidural steroid injections, though patients allocated to surgery who did receive epidural steroid injections were more likely to crossover to non-surgical treatment (4). However, this analysis was rife with methodological flaws and conflicts with numerous controlled studies and systematic reviews that have demonstrated the effectiveness of epidural injections (5-41). One of the challenges in evaluating these studies is that none have rigorously addressed the role of selective nerve root blocks in selecting patients for surgical interventions, specifically in the lumbar spine. It is well-documented that lumbar disc herniation is often seen on imaging studies in the absence of symptoms (42-50), and can regress over time without surgery (44-46), yet the role of selective nerve root blocks in confirming radicular pain has not been systematically evaluated (50-62).

In view of the fact that abnormalities found on imaging studies are frequently painless, pain originating from the spine can be difficult to diagnose, and the particular structure(s) responsible for symptoms can be challenging to isolate $(42,43,48-62)$. Excluding fractures, disorders of the spine that can produce pain may be categorized as compressive, inflammatory, degenerative, and/ or multifactorial.

In a recent editorial, Shah (62) outlined the problems with diagnostic selective nerve root blocks. He argued that, whereas many practitioners consider the premise behind selective nerve blocks to be valid "prima facie" (self-evident), rendering any hypothesis immune to challenge damages its scientific integrity (62-64). Despite the untenability of this philosophy, (62), the value and validity of diagnostic nerve blocks continue to be extensively described and debated (65-75). Shah (62) criticized the current debate on the grounds that it focuses on diagnostic accuracy, technique optimization and patient selection, contending that selective nerve root blocks cannot be used to diagnose pain. Nevertheless, substantial literature has been published on the utility of diagnostic selective nerve root blocks, even without the procedure being validated $(51,62,76-88)$.

For a structure to be painful, it must have a nerve supply (58), be susceptible to disease or injury, and a connection must be established between the injury or disease and a clinical pain condition. Methods have been developed to test painful structures using fluoroscopically (X-ray) guided injections of local anesthetics. If a structure is selectively anesthetized and the individual describes pain relief for the duration of action of the anesthetic, that structure is suspected to be the source of pain (58). For compressive and inflammatory disorders of spinal nerve roots, the likely area for the presence of pathology is within the bony channel created between adjacent vertebrae at the neural foramen (53).

The International Association for the Study of Pain (IASP) (54) defines radicular pain as pain perceived as arising in a limb or trunk that is caused by ectopic activation of nociceptive afferent fibers in a spinal nerve or its root(s), or related neuropathic mechanisms. The IASP defines lumbar radiculopathy as the objective loss of sensory and/or motor function as a result of a connection block in the axons of a spinal nerve or its root(s). The term lumbar radiculitis implies that the inflammatory process is solely responsible for the causation of radicular signs and symptoms, which is often incorrect. Hence, the term "lumbar radicular syndrome" may be most accurate in that it correctly suggests a constellation of clinical signs and symptoms of variable etiologies secondary to pathology or dysfunction of nerve root(s) or dorsal root ganglia. Although chronic low back pain is highly prevalent $(50,54)$, the prevalence of radicular pain is somewhat lower, ranging from $17 \%$ to a little over $50 \%$ using validated instruments (89-93). In 2 studies using strict criteria, the lifetime prevalence of radiculopathy due to a herniated lumbar disc was estimated to be $4 \%$ in females and $5 \%$ in males $(57,94)$. The 2 most common causes of neuropathic spinal pain are lateral recess/ foraminal stenosis and herniated disc (59-61). In some cases, both etiologies may be present, as well as central spinal stenosis. Apart from mechanical compression, various biochemical, toxic factors have been identified as a cause of radiculitis. Schoenfeld et al (56) characterized the incidence and risk factors for the development of lumbar radiculopathy based on the US 
Departmnet of Defense Medical Epidemiology Database for the years 2000 to 2009. They estimated the overall incidence of lumbar radiculopathy to be 4.86 per 1,000 person-years. They also found that service members 30 years of age and older had a greater than 3-fold risk of developing lumbar radiculopathy when compared to individuals less than 20 years old.

These distinctions illustrate that radiculopathy is not synonymous with radicular pain or nerve root pain. The terms "radicular pain" and "nerve root pain" specifically apply to a single symptom - pain - that arises from one or more spinal nerve roots (95). The accurate diagnosis of spinal pain is important in helping clinicians make individual treatment decisions $(65-74,96-101)$. It is well-known that obtaining a precise diagnosis can often be elusive. Many authors have attempted to investigate improved methods of classifying or diagnosing patients with spine-related pain. It is widely held that accurate diagnosis is derived from a combination of history taking, physical examination, and radiological assessment. However, the evidence shows that these assessments may not be accurate, especially with regard to specificity $(47,50-74,102)$. One of the impediments that can hinder accurate diagnosis is that nerve root pain does not necessarily follow along a specific dermatome pattern or may involve multiple dermatomes $(55,103-108)$. In an experimental study of 25 patients with radicular pain in the lower extremity, Bove et al (106) reported that all patients reported the pain as deep, rather than on the skin, which questions the value of classic dermatomal maps. In a study involving the evaluation of 30 patients with cervical radiculopathy and multi-level spinal degeneration using selective nerve root blocks, Anderberg et al (107) found only a $28 \%$ correlation between the dermatomal distribution of neurological deficits/radicular pain and the putative symptomatic nerve root. In an assessment of 226 nerve roots in 169 patients, Murphy et al (55) found that pain related to cervical nerve roots was non-dermatomal in over twothirds $(69.7 \%)$ of cases and was non-dermatomal in just under two-thirds $(64.1 \%)$ of cases in the lumbar spine. The nerve roots with the highest degree of sensitivity and specificity were $\mathrm{C} 4$ in the cervical spine (sensitivity $60 \%$, specificity $72 \%$ ) and $\mathrm{S} 1$ in the lumbosacral spine (sensitivity $65 \%$, specificity $80 \%$ ). The authors concluded that, in most cases, nerve root pain does not follow a specific dermatome pattern, and that the distribution of pain is not generally a useful historical factor in the diagnosis of radicular pain, with the possible exception of S1. In a retrospective study evaluating adjacent double nerve root blocks in 132 patients with unilateral radiculopathy, Bartynski et al (108) demonstrated adjacent double-level replication of the patient's familiar pain in $62 \%$ of patients, single root replication in $37(28 \%)$, and no response in 13 or $10 \%$. The authors concluded that adjacent double-level contributions to lumbar radiculopathy are common, and that clinical imaging clues should be assessed to ensure an optimum response to nerve root block/steroid injection (108).

Spinal injections have generated considerable interest in the medical community, particularly epidural steroid injections in which precision placement has been facilitated by the use of radiological imaging (5-40). The indications for epidural steroid injections include radicular pain, spinal stenosis, and possibly discogenic pain (5-40). However, there is no consistent method for using foraminal and nerve root injections as diagnostic tools. Controversy surrounds even the nomenclature itself $(51,62,109-121)$. Manchikanti (118) and Manchikanti and Singh (121) noted that the terminology describing transforaminal injections has varied from nerve root injections to selective nerve root blocks, selective nerve root sleeve injections, selective epidurals, selective spinal nerve blocks, selective ventral ramus blocks, and periradicular injections. Bogduk (75) labeled the procedure as a lumbar nerve block, in which an aliquot of local anesthetic is delivered onto lumbar spinal nerve (or the SI spinal nerve) in order to selectively anesthetize the nerve and its roots.

Gajraj (76) noted that "...to be selective, a nerve root block should be performed extraforaminally, distal to the division of the ventral and dorsal rami; otherwise the dorsal rami and all its innervated structures will also be anesthetized...it has therefore been suggested that the therapeutic procedure be referred as a 'transforaminal epidural steroid injection' and that the diagnostic procedure be referred to as a 'selective spinal block' or 'selective ventral ramus block.'" Datta and Pai (77) noted that the term "transforaminal" is a misnomer and gives the false impression that the needle actually traverses the foramen, when in actuality it is positioned paraforaminally. They suggested that the term "selective nerve root block" be rephrased as a "paraforaminal injection" because no preferential distribution of the injected medication extends to the ventral ramus. Other suggested nomenclature includes the terms "periradicular," "nerve root infiltration," "transforaminal selective nerve root block," "segmental nerve root block," and "lumbar nerve block" $(51,75-81,117,118,120)$. 
Most recently, Shah (62) postulated that selective nerve root blocks, as commonly performed and interpreted, are incapable of diagnosing spinal pathology. He asserted that there was no role for diagnostic selective nerve root blocks in the identification of pain generators, and that it be considered only therapeutic.

In the United States, the official term for this procedure is "transforaminal epidural injection." There is no other code to communicate with insurers and the government. Some use anesthetic alone; others use a low steroid dose, arguing that the steroid should not effectuate an immediate response. The volumes used in the injection also vary, with some using a large volume and others using a smaller volume consistent with the amount necessary to reach the lateral recess. Manchikanti and Singh (121) noted that Karppinen et al $(112,117,120)$ injected $0.5-1.0 \mathrm{~mL}$ of contrast for diagnostic purposes, followed by a therapeutic injection of methylprednisolone $40 \mathrm{mg}$, bupivacaine, or isotonic sodium chloride solution in a volume of $2 \mathrm{~mL}$ for $\mathrm{L} 4$ or L5 blocks, and $3 \mathrm{~mL}$ for S1, presumably based on anatomical differences. Higher volumes of injectate may result in more extensive blockade, thereby undermining the specificity. In a 2008 study by Furman et al (82), the authors found that lumbar segmental nerve root blocks cannot be considered diagnostically selective if volumes exceed $0.5 \mathrm{~mL}$. These results are consistent with those of Castro et al (122), who randomized 94 patients to undergo CT-guided L4 nerve root injections using $0.5 \mathrm{~mL}, 1 \mathrm{~mL}$, or $2 \mathrm{~mL}$ of contrast. Epidural spread was noted in $48 \%$ of patients in the $0.5 \mathrm{~mL}$ group, $67 \%$ in the $1 \mathrm{~mL}$ group and $75 \%$ of subjects injected with 2 $\mathrm{mL}$. Definitive spread to an adjacent nerve root was also common, occurring in $24 \%$ of the $0.5 \mathrm{ml}$ group, $27 \%$ of the $1 \mathrm{ml}$ group and $33 \%$ of injections done with $2 \mathrm{ml}$ of contrast. Spread into the psoas muscle, where the nerve roots converge to become a plexus, was found to occur in $12 \%$ of patients in the $0.5 \mathrm{ml}$ group, $33 \%$ of subjects who received $1 \mathrm{ml}$ injections, and $68 \%$ of people who were injected with $2 \mathrm{ml}$ contrast. In the cervical region, Anderberg et al (123) found that selective nerve blocks performed with $0.6 \mathrm{ml}$ were equally effective, but more sensitive, than those done with $1.1 \mathrm{ml}$ or 1.7 $\mathrm{ml}$ of contrast. Specifically, the use of higher volumes increased the likelihood of anesthetizing an adjacent nerve root. Ironically, in later publications, Furman et al $(83,84)$ reported that the volume of contrast needed to reach specific landmarks in lumbar transforaminal epidural injections was $4 \mathrm{~mL}$ for lumbar levels and $3 \mathrm{~mL}$ for $\mathrm{S} 1$. Purists insist on describing selective nerve root block and transforaminal injections as 2 separate and distinct techniques, though over the years many have used the terms interchangeably. Despite variations in practice, the technique holds promise as a diagnostic tool, but its reliability is unclear $(51,85,118)$.

The value of provocative and analgesic spinal injections was recognized in 1938 by Steindler and Luck (85). In 1971, MacNab (86) demonstrated the value of diagnostic selective nerve root blocks in the preoperative evaluation of patients with negative or inconclusive imaging studies and clinical findings of nerve root irritation. Since then, nerve blocks have been used to diagnose the source of radicular pain when imaging studies suggested possible compression of several nerve roots (51).

Lumbar spinal nerve blocks have been considered to have concept validity because anesthetizing a nerve should theoretically relieve symptoms mediated by that nerve (75). Face validity is established by injecting contrast and local anesthetic under fluoroscopy to delineate the targeted nerve root and ensure that contrast has not spread to other structures. To establish construct validity, selective nerve root blocks must be performed under controlled conditions to avoid falsepositive results. Thus far, there are no descriptions of the procedure using these parameters. When selective nerve root blocks are performed, they are often assumed to be specific (i.e. no false-positive results) (75). However, Shah (62) questioned this contention, noting that rendering hypotheses such as this one immune to challenge damages their scientific integrity (62-64).

In 1992, Nachemson (87) analyzed the literature on low back pain and concluded that diagnostic, selective nerve root blocks provided important prognostic information about surgical outcomes. Van Akkerveeken (88) described the sensitivity, specificity, and predictive value for diagnostic, selective nerve root blocks. He also asserted that for a block to be considered positive, it required both symptom reproduction during root stimulation and complete relief of pain following anesthetic infusion. A systematic review from 2007 (51) concluded that there was limited evidence to support the validity of selective nerve root injections as a diagnostic tool for spinal pain, but that the available literature did support selective nerve root injections as a diagnostic test for equivocal radicular pain. The review stated that there was moderate evidence for use in the preoperative evaluation of patients with negative or inconclusive imaging studies. The potential benefits of performing selective nerve root blocks must be balanced against the potential for complications related to se- 
lective nerve blocks/transforaminal epidural injections $(7,36,47,124-149)$.

This systematic review was undertaken to update the previous review, and to determine if selective nerve root injections are an effective method for diagnosing spinal disorders (51).

\subsection{Methods}

The methodology utilized in this systematic review followed the review process derived from evidencebased systematic reviews and meta-analyses of diagnostic accuracy studies (37,72-74,150-156).

\subsection{Criteria for Considering Studies for This Review}

\subsubsection{Types of Studies}

Diagnostic accuracy studies evaluating selective nerve root injections.

\subsubsection{Types of Participants}

Participants of interest were adults aged at least 18 years with chronic low back and lower extremity pain of at least 6 weeks duration.

Participants must have failed previous pharmacotherapy, exercise therapy, etc., prior to starting diagnostic interventional pain management techniques.

\subsubsection{Types of Interventions}

The interventions were selective nerve root injections appropriately performed with proper technique under fluoroscopic or CT guidance.

\subsubsection{Types of Outcome Measures}

- The primary outcome parameter was concordant pain relief.

- The secondary outcome measure was the ability to perform previously painful movements without significant pain or complications.

- At least 2 of the review authors independently, in an unblinded standardized manner, assessed the outcomes measures. Any disagreements between reviewers were resolved by a third author and consensus.

\subsection{Literature Search}

Searches were performed from the following sources without language restrictions:

1. PubMed from 1966 www.ncbi.nlm.nih.gov/sites/entrez?db=pubmed
2. EMBASE from 1980

www.embase.com/

3. Cochrane Library www.thecochranelibrary.com/view/0/index.html

4. U.S. National Guideline Clearinghouse (NGC) www.guideline.gov/

5. Previous systematic reviews and cross references

6. Clinical Trials

clinicaltrials.gov/

The search period was from 1966 through September 2012.

\subsection{Search Strategy}

The search strategy emphasized lumbar radicular pain and diagnostic selective nerve root injections.

The search terms included: "low back pain", "lumbar radiculitis", "lumbar radicular pain", "selective nerve root injection", "nerve root block", "segmental nerve root block", and "transforaminal epidural injection."

This systematic review focused only on selective nerve root injections performed under fluoroscopic or CT imaging techniques. Interventional techniques performed blindly or using other identification modalities were excluded. All studies describing appropriate outcome evaluations with proper statistical evaluations were reviewed. Reports without appropriate diagnosis, non-systematic reviews, book chapters, and case reports were excluded.

At least 2 of the review authors independently, in an unblinded standardized manner, performed each search. Accuracy was confirmed by a statistician. Searches were combined to obtain a unified search strategy. Any disagreements between reviewers were resolved by a third author and consensus.

\subsection{Data Collection and Analysis}

The quality of each individual article used in this assessment was based on the Quality Appraisal of Reliability Studies (QAREL) checklist (Table 1) (150). This checklist has been validated and utilized in multiple systematic reviews (151). Each study in the final sample of eligible manuscripts was assessed using a 12-item appraisal checklist designed to assess the quality and applicability of studies. The face validity of these checklists was established by consultation with methodology experts (150) and comparison with quality appraisal checklists used in other systematic reviews examining diagnostic reliability 
Table 1. Quality Appraisal of Diagnostic Reliability (QAREL) checklist.

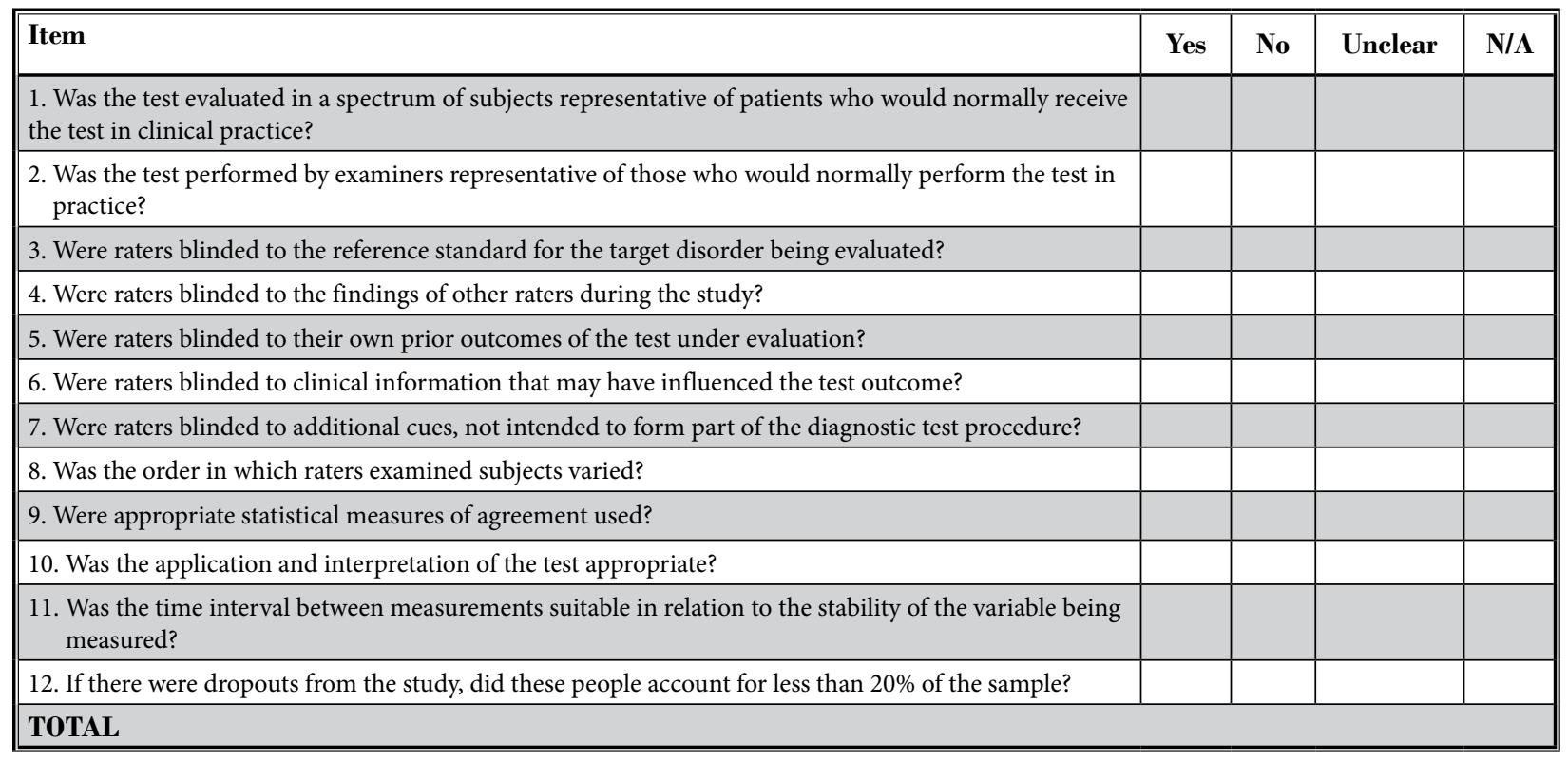

Lucas N, et al. The development of a quality appraisal tool for studies of diagnostic reliability (QAREL). J Clin Epidemiol 2010; 63:854-861 (150).

(157-162). This checklist was also developed in accordance with the Standards for Reporting Studies of Diagnostic Accuracy (STARD) (153), and the Quality Assessment of Diagnostic Accuracy Studies (QUADAS) $(154,156)$ appraisal tools. Studies were not given an overall numeric quality score; instead, each item was considered separately and graded as "yes," "no," "unclear," or "not applicable."

\subsubsection{Selection of Studies}

- In an unblinded standardized manner, 2 review authors screened the abstracts of all identified studies against the inclusion criteria.

- All articles with possible relevance were then retrieved in full text for comprehensive assessment of internal validity, quality, and adherence to inclusion criteria.

\subsubsection{Inclusion and Exclusion Criteria}

The following were the inclusion and exclusion criteria:

1. Are the patients described in sufficient detail to allow one to decide whether they are comparable to those who are treated in interventional pain management clinical practices?

A. Setting-office, hospital, outpatient, inpatient.

B. Physician - interventional pain physician, general physician, anesthesiologist, physiatrist, neurologist, rheumatologist, orthopedic surgeon, neurosurgeon, etc.

C. Patient characteristics - duration of pain.

D. Noninterventional techniques or surgical interventions in the past.

2. Is the intervention described in sufficient detail to enable one to apply its use to patients in interventional pain management settings?
A. Nature of intervention.
B. Frequency of intervention.
C. Duration of intervention.

3. Were clinically relevant outcomes measured?
A. Proportion of pain relief.
B. Disorder/specific disability.
C. Functional improvement.
D. Allocation of eligible and non-eligible patients to return to work.
E. Ability to work.

\subsubsection{Clinical Relevance}

The clinical relevance of the included studies was evaluated according to 5 questions recommended by the Cochrane Back Review Group (Table 2) $(163,164)$. Each question was scored as positive $(+)$ if the clinical relevance item was met, negative $(-)$ if the item was not met, and unclear (?) if data were not available to answer the question. 
Table 2. Clinical relevance questions.

\begin{tabular}{|c|c|c|c|}
\hline & $\mathbf{P ( + )}$ & $\mathbf{N}(-)$ & U (unclear) \\
\hline $\begin{array}{l}\text { A) Are the patients described in detail so that one can decide whet } \\
\text { are treated in practice? }\end{array}$ & & & \\
\hline $\begin{array}{l}\text { B) Are the interventions and treatment settings described in suffic } \\
\text { practice? }\end{array}$ & & & \\
\hline C) Were clinically relevant outcomes measured and reported? & & & \\
\hline D) Is the size of the effect clinically meaningful? & & & \\
\hline E) Do the likely treatment benefits outweigh the potential harms? & & & \\
\hline
\end{tabular}

Scoring adapted and modified from Staal JB, et al. Injection therapy for subacute and chronic low-back pain. Cochrane Database Syst Rev 2008; 3:CD001824 (164).

Table 3. Method for grading the overall strength of the evidence for an intervention.

\begin{tabular}{|l|l||}
\hline \multicolumn{1}{|c|}{ Grade } & \multicolumn{1}{c|}{ Definition } \\
\hline Good & $\begin{array}{l}\text { Evidence includes consistent results from well-designed, well-conducted studies in representative populations that directly } \\
\text { assess effects on health outcomes (at least 2 consistent, higher-quality RCTs or studies of diagnostic test accuracy). }\end{array}$ \\
\hline Fair & $\begin{array}{l}\text { Evidence is sufficient to determine effects on health outcomes, but the strength of the evidence is limited by the number, qual- } \\
\text { ity, size, or consistency of included studies; generalizability to routine practice; or indirect nature of the evidence on health } \\
\text { outcomes (at least one higher-quality trial or study of diagnostic test accuracy of sufficient sample size; 2 or more higher- } \\
\text { quality trials or studies of diagnostic test accuracy with some inconsistency; at least 2 consistent, lower-quality trials or studies } \\
\text { of diagnostic test accuracy, or multiple consistent observational studies with no significant methodological flaws). }\end{array}$ \\
\hline Limited or Poor & $\begin{array}{l}\text { Evidence is insufficient to assess effects on health outcomes because of limited number or power of studies, large and unex- } \\
\text { plained inconsistency between higher-quality trials, important flaws in trial design or conduct, gaps in the chain of evidence, } \\
\text { or lack of information on important health outcomes. }\end{array}$ \\
\hline
\end{tabular}

Adapted and modified from methods developed by U.S. Preventive Services Task Force $(37,166,167)$.

\subsubsection{Methodological Quality or Validity Assessment}

Each study was evaluated by at least 2 authors for stated criteria and any disagreements discussed with a third reviewer. Authors with a perceived conflict of interest for any manuscript were recused from reviewing the manuscript.

Only diagnostic accuracy studies meeting at least $50 \%$ of applicable inclusion criteria were included for analysis. Studies scoring less than $50 \%$ are reported descriptively with critical analysis.

\subsubsection{Data Extraction and Management}

Two review authors independently, in an unblinded standardized manner, extracted the data from the included studies. Disagreements were resolved by discussion between the 2 reviewers; if no consensus could be reached, a third author was called in to break the impasse.

\subsubsection{Assessment of Heterogeneity}

Whenever meta-analyses were conducted, the Isquared (I2) index was used to identify heterogeneity
(165). Combined results with $12>50 \%$ were considered substantially heterogenous.

\subsubsection{Measurement of Treatment Effect in Data Synthesis (Meta-Analysis)}

Data were separately summarized using metaanalysis when at least 5 studies were included.

\subsection{Summary Measures}

Summary measures included at least $50 \%$ pain relief with the capability of performing previously painful movements concordant with the duration of action of local anesthetic.

\subsection{Analysis of Evidence}

The analysis of the evidence was performed based on United States Preventive Services Task Force (USPSTF) criteria (166), as illustrated in Table 3, which has been utilized by multiple authors $(37,65-71,167)$.

The analysis was conducted using 3 levels of evidence: good, fair, or limited or poor.

At least 2 of the review authors independently, in an unblinded standardized manner, analyzed the 
evidence. Any disagreements between reviewers were resolved by a third author and consensus. If there were any conflicts of interest (e.g., authorship), those reviewers were recused from assessment and analysis.

\subsection{Outcome of the Studies}

Outcomes included the accuracy of selective nerve root injections in the lumbar spine. Based on the above parameters, the reliability of the data derived from each study was assessed.

\subsection{Results}

Figure 1 shows a flow diagram of study selection. There were 58 studies considered for inclusion (79$85,88,94-121,123,168-188)$. The list of select excluded studies of diagnostic lumbar nerve root injections is provided in Table $4(83-87,106,108,123,168,176-181,185)$.

\subsection{Diagnostic Accuracy Studies}

Table 5 illustrates the characteristics of studies considered for inclusion. Overall, 19 studies were included $(78-82,88,169-175,182,183,185-188)$. Among these, 3 studies assessed contrast flow selectivity or flow patterns (80-82). One study assessed the distinct sensory effects of selective nerve root block (79). One study assessed the role of adjacent double-nerve root contributions in unilateral lumbar radiculopathy (108). A total of 15 studies evaluated diagnostic accuracy $(88,169-175,182-188)$.

\subsection{Clinical Relevance}

Among the 19 studies assessed for clinical relevance (78-82,88, 169-175,182,183,185-188), all studies met criteria with a score of 3 of 5 or greater. Table 6 illustrates the assessment of clinical relevance.

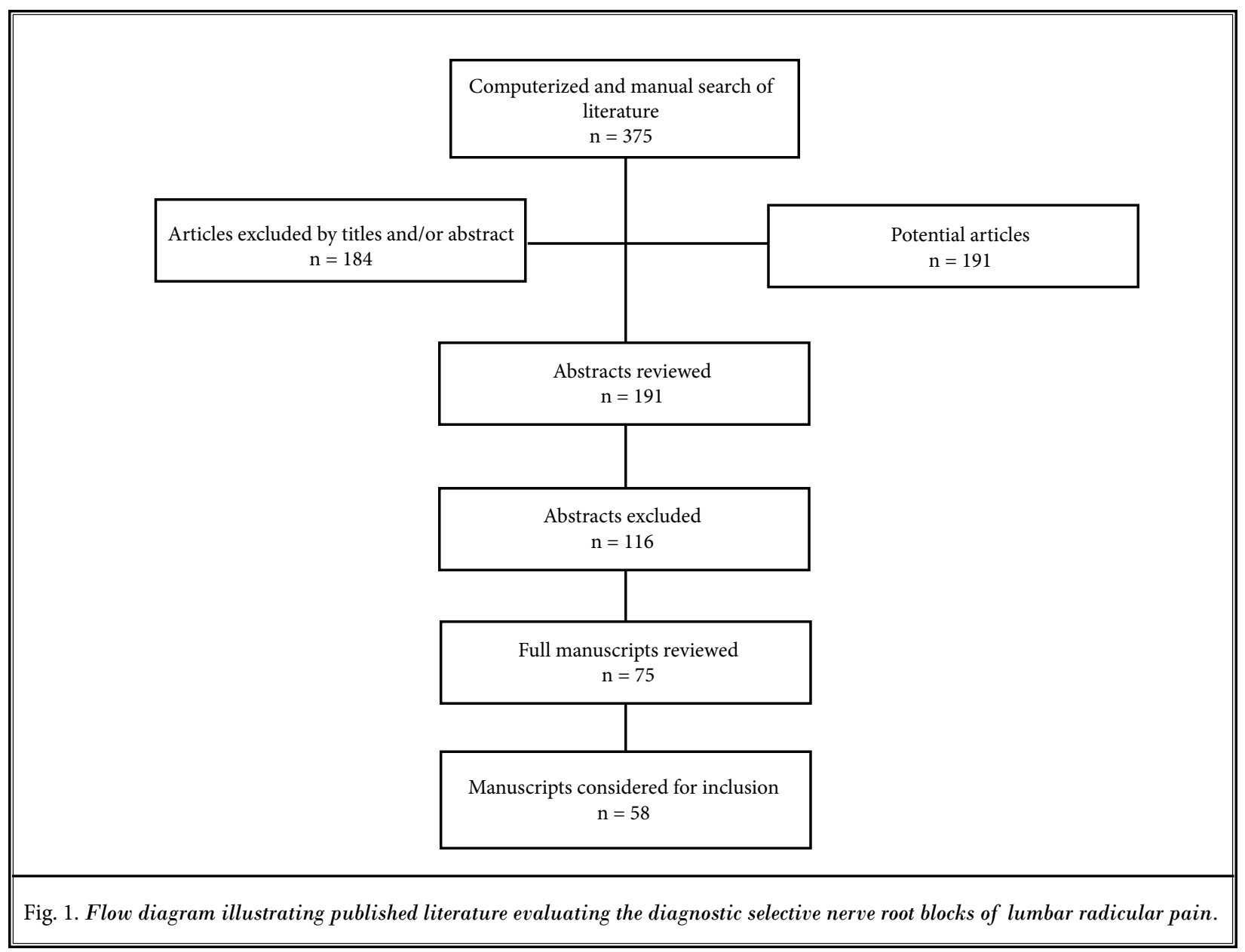


Table 4. List of select excluded studies of diagnostic lumbar nerve root injections.

\begin{tabular}{|c|c|}
\hline Manuscript Author(s) & Reason for Exclusion \\
\hline Furman et al, 2010 (83) & $\begin{array}{l}\text { The authors studied injectate volumes needed to reach specific landmarks for lumbar transforaminal epidural } \\
\text { injections, showing that } 4 \mathrm{~mL} \text { of contrast was needed. }\end{array}$ \\
\hline Furman et al, $2012(84)$ & $\begin{array}{l}\text { The authors studied injectate volumes needed to reach specific landmarks for S1 transforaminal epidural injec- } \\
\text { tions and showed that } 3 \mathrm{~mL} \text { was required to reach the superior aspect of the } \mathrm{L} 5 / \mathrm{S} 1 \text { intervertebral disc. }\end{array}$ \\
\hline Steindler \& Luck, 1938 (85) & $\begin{array}{l}\text { This is the first description of identifying the source of pain using the procaine hydrochloride method described } \\
\text { by the authors. Despite its importance, the study does not describe the accuracy of selective nerve root blocks. }\end{array}$ \\
\hline MacNab, $1971(86)$ & $\begin{array}{l}\text { Analyzed the causes of nerve root involvement with negative surgical findings in } 68 \text { patients in one of the earliest } \\
\text { published studies. However, the accuracy of selective nerve root blocks was not evaluated. }\end{array}$ \\
\hline Nachemson, $1992(87)$ & $\begin{array}{l}\text { Nachemsom described various issues related to low back pain without assessing the accuracy of selective nerve } \\
\text { root blocks. }\end{array}$ \\
\hline Bove et al, 2005 (106) & $\begin{array}{l}\text { This study assessed the incidence of superficial versus deep pain localization among patients with lumbar radicu- } \\
\text { lar pain, noninvasively by questioning, without selective nerve root blocks. }\end{array}$ \\
\hline Bartynski et al, 2010 (108) & $\begin{array}{l}\text { In this evaluation, unilateral lumbar nerve root block was performed in } 350 \text { patients with lumbar radicular pain. } \\
\text { The accuracy of selective nerve root blocks was not assessed. The study was geared to evaluate adjacent double- } \\
\text { nerve root contributions in unilateral lumbar radiculopathy. }\end{array}$ \\
\hline Hoppenstein, 1980 (168) & $\begin{array}{l}\text { The authors evaluated a new approach to failed back surgery syndrome by performing a series of differential } \\
\text { nerve blocks followed by microsurgical dorsal root rhizotomy. The accuracy of selective nerve root blocks was } \\
\text { not evaluated. }\end{array}$ \\
\hline Pfirrmann et al, 2001 (176) & $\begin{array}{l}\text { Authors assessed the response to selective nerve root blocks for the treatment of sciatica based on the injection } \\
\text { site. However, there was no diagnostic information. }\end{array}$ \\
\hline Wagner, 2004 (177) & $\begin{array}{l}\text { The author evaluated the technique, results, procedure time, and radiation dose of selective nerve root blocks. } \\
\text { However, accuracy was not studied. }\end{array}$ \\
\hline Kim et al, $2012(178)$ & The authors studied contrast dispersal patterns in retrodiscal transforaminal epidural steroid injections. \\
\hline Miyakoshi et al, 2007 (179) & In this preliminary study, total dorsal ramus block for the treatment of chronic low back pain was described. \\
\hline Chua et al, 2011 (180) & $\begin{array}{l}\text { This study evaluated whether diagnostic blocks have a beneficial effect on pain processing. It did not assess } \\
\text { diagnostic accuracy. }\end{array}$ \\
\hline Anderberg et al, 2006 (123) & The study evaluated distribution patterns of transforaminal injections in the cervical, rather than lumbar spine. \\
\hline Slipman et al, 1998 (181) & $\begin{array}{l}\text { The study evaluated symptom provocation for fluoroscopically cervical nerve root stimulation, rather than } \\
\text { lumbar spine. }\end{array}$ \\
\hline Anderberg et al, $2004(184)$ & $\begin{array}{l}\text { The authors correlated selective nerve root block results with clinical symptoms and magnetic resonance imaging } \\
\text { pathology in the cervical, but not lumbar spine. }\end{array}$ \\
\hline
\end{tabular}

\subsection{Methodological Quality Assessment}

A methodological quality assessment of diagnostic accuracy studies meeting inclusion criteria was carried out utilizing QAREL criteria as shown in Table 7. Studies achieving $50 \%$ or higher scores were included. Scores of $67 \%$ or higher were considered to be high quality, $50 \%-66 \%$ were considered to be moderate quality, and studies scoring less than $50 \%$ were considered to be of poor quality and excluded.

\subsection{Meta-Analysis}

All diagnostic accuracy studies were evaluated for homogeneity for inclusion in the meta-analysis. No meta-analysis was performed due to the lack of homogeneity among the studies.

\subsection{Analysis of Evidence}

The evidence was synthesized based on the relief criteria when selective nerve root injections were performed. Table 8 illustrates the results of diagnostic accuracy studies.

Based on the USPSTF criteria, the evidence was classified to be good, fair, or limited or poor.

The evidence is limited based on 10 of 14 studies providing positive evidence assessing accuracy.

\subsection{Complications}

The most common and worrisome complications of transforaminal epidural steroid injections in the lumbar spine are related to neural trauma, vascular trauma, intravascular injection, and infection (189- 
Table 5. Characteristics of reported diagnostic accuracy studies.

\begin{tabular}{|c|c|c|c|c|c|}
\hline Study/Year & Participants & Interventions(s) & Outcomes & Result(s) & Conclusion(s) \\
\hline $\begin{array}{l}\text { Faraj and } \\
\text { Mulholland, } \\
2006 \text { (78) } \\
\text { Prospective } \\
\text { case series }\end{array}$ & $\begin{array}{l}96 \text { patients } \\
\text { with leg pain }\end{array}$ & $\begin{array}{l}\text { Nerve root block } \\
\text { with and without a } \\
\text { nerve stimulator, epi- } \\
\text { durogram obtained }\end{array}$ & $\begin{array}{l}\text { Comparison of } \\
\text { response rate of SNRB } \\
\text { with and without use } \\
\text { of a neurostimulator. }\end{array}$ & $\begin{array}{l}\text { Response rate } 89 \% \text {. The response rate } \\
\text { for lateral canal stenosis and battered } \\
\text { root syndrome were higher than for } \\
\text { post-discectomy or disc prolapse pain. } \\
\text { Response rate was } 96 \% \text { when blocks } \\
\text { were guided by a neurostimulator vs. } \\
79 \% \text { when no neurostimulator was used. }\end{array}$ & $\begin{array}{l}\text { Neurostimulation } \\
\text { may improve the ac- } \\
\text { curacy of nerve root } \\
\text { blocks. Accuracy } \\
\text { of diagnostic SNRB } \\
\text { was not assessed. }\end{array}$ \\
\hline $\begin{array}{l}\text { Wolff et al, } \\
2006 \text { ( } 79) \\
\text { Prospective, } \\
\text { randomized, } \\
\text { double blind, } \\
\text { crossover } \\
\text { study }\end{array}$ & $\begin{array}{l}10 \text { pa- } \\
\text { tients with } \\
\text { radiculopathy }\end{array}$ & $\begin{array}{l}\text { Lumbar SNRB at } \\
\text { L4 with ropivacaine } \\
0.25 \% \text { or lidocaine } \\
1 \%\end{array}$ & $\begin{array}{l}\text { Comparison of SNRB } \\
\text { with baseline mea- } \\
\text { surements in patients } \\
\text { with chronic low back } \\
\text { pain radiating to leg } \\
\text { with maximum pain } \\
\text { in one dermatome } \\
\end{array}$ & $\begin{array}{l}\text { Asymptomatic hypoesthesia variable } \\
\text { in extent and nondermatomal in } 7 / 10 \\
\text { patients. SNRB produced no consis- } \\
\text { tent change in extent and distribution } \\
\text { of hypoesthetic area. }\end{array}$ & $\begin{array}{l}\text { Pre-block assess- } \\
\text { ment of sensory } \\
\text { function is essential } \\
\text { to assess net effects } \\
\text { of SNRB. Accuracy } \\
\text { of diagnostic SNRB } \\
\text { was not assessed. } \\
\end{array}$ \\
\hline $\begin{array}{l}\text { Wolff et al, } \\
2006(80) \\
\text { Prospective, } \\
\text { observational } \\
\text { study }\end{array}$ & $\begin{array}{l}71 \text { patients for } \\
\text { L4, L5, and S1 } \\
\text { SNRB }\end{array}$ & $\begin{array}{l}\text { Using electrostimu- } \\
\text { lation, } 0.5 \mathrm{~mL} \text { of } \\
\text { lidocaine and iohexol } \\
\text { injected }\end{array}$ & $\begin{array}{l}\text { Evaluation of epidural } \\
\text { spread and spread to } \\
\text { adjacent nerve roots }\end{array}$ & $\begin{array}{l}\text { Epidural spread in } 47 \% \text { of L4 and } \\
28 \% \text { of L5 blocks. Spread into adja- } \\
\text { cent nerve roots occurred in } 5 \% \text { of } \\
\text { injections. } \\
\text { Risk of epidural and/or adjacent } \\
\text { nerve root spread present even with } \\
\text { low injection volume of } 0.5 \mathrm{~mL} \text {, } \\
\text { increasing with more medial needle } \\
\text { position. Suggest susing electro- } \\
\text { stimulation along with fluoroscopy to } \\
\text { achieve optimal results. }\end{array}$ & $\begin{array}{l}\text { This study sug- } \\
\text { gests that the } \\
\text { validity of SNRB is } \\
\text { questionable. }\end{array}$ \\
\hline $\begin{array}{l}\text { Vassiliev, } \\
2007(81) \\
\text { Observational } \\
\text { study }\end{array}$ & $\begin{array}{l}39 \text { patients } \\
\text { with chronic } \\
\text { lumbar } \\
\text { radiculopathy }\end{array}$ & $\begin{array}{l}\text { SNRB with injection } \\
\text { of contrast in } 1 \\
\mathrm{~mL} \text { increments } 10 \\
\text { seconds apart up to } 3 \\
\mathrm{~mL} \text { at each level. }\end{array}$ & $\begin{array}{l}\text { Positive "spread" was } \\
\text { defined as visualiza- } \\
\text { tion of the adjacent } \\
\text { nerve root with } \\
\text { contrast. }\end{array}$ & $\begin{array}{l}\text { During L4 and L5 SNRB, contrast } \\
\text { spread to the subjacent nerve root } \\
\text { occurred in } 46.1 \% \text { and } 57.7 \% \text { of } \\
\text { subjects, respectively. There was } \\
\text { significant difference between the } \\
\text { spread of contrast onto the medially } \\
\text { located nerve root in the same lum- } \\
\text { bar segment and nerve roots in the } \\
\text { lumbar segment above. } \\
\text { Injection of } 1 \mathrm{~mL} \text { of contrast under } \\
\text { fluoroscopic guidance does not } \\
\text { guarantee selective spread of contrast } \\
\text { around targeted nerve roots. }\end{array}$ & $\begin{array}{l}\text { This study reinforc- } \\
\text { es the questionable } \\
\text { accuracy of SNRB. }\end{array}$ \\
\hline $\begin{array}{l}\text { Furman et al, } \\
2008(82) \\
\text { Prospective } \\
\text { evaluation }\end{array}$ & $\begin{array}{l}30 \text { patients } \\
\text { with lumbar } \\
\text { radiculitis }\end{array}$ & $\begin{array}{l}\text { SNRB with injec- } \\
\text { tion of } 4 \mathrm{~mL} \text { of } \\
\text { nonionic contrast in } \\
\text { incremental doses of } \\
0.5 \mathrm{~mL} .\end{array}$ & $\begin{array}{l}\text { Assessment of con- } \\
\text { trast flow selectivity } \\
\text { during transforaminal } \\
\text { lumbosacral epidural } \\
\text { steroid injections }\end{array}$ & $\begin{array}{l}\text { After administration of } 0.5 \mathrm{~mL} \text { of } \\
\text { contrast, } 30 \% \text { of injections were no } \\
\text { longer "selective" for specified root } \\
\text { level. After administration of } 1 \mathrm{~mL} \text {, } \\
1.5 \mathrm{~mL} \text { and } 2.5 \mathrm{~mL} \text { of contrast, } 67 \% \text {, } \\
87 \% \text { and } 95 \% \text { of injections, respec- } \\
\text { tively, were no longer "selective". }\end{array}$ & $\begin{array}{l}\text { Even with low } \\
\text { volumes, this study } \\
\text { also raises questions } \\
\text { regarding the selec- } \\
\text { tivity of nerve root } \\
\text { injections. }\end{array}$ \\
\hline $\begin{array}{l}\text { Van Ak- } \\
\text { kerveeken, } \\
1993(88) \\
\text { Prospective } \\
\text { case series }\end{array}$ & $\begin{array}{l}46 \text { ( } 37 \text { patients } \\
\text { with disc } \\
\text { protrusions } \\
\text { and } 9 \text { with } \\
\text { metastases) }\end{array}$ & $\begin{array}{l}\text { Mechanical stimula- } \\
\text { tion followed by } \\
\text { SNRB with Marcaine }\end{array}$ & $\begin{array}{l}\text { Comparison of } \\
\text { SNRB response to } \\
\text { imaging and surgical } \\
\text { pathology }\end{array}$ & $\begin{array}{l}\text { Sensitivity } 100 \% \text {, specificity } 90 \% \\
\text { for injections. Positive predictive } \\
\text { value for good surgical result ranged } \\
\text { between } 70-95 \% \text { depending on } \\
\text { statistics. }\end{array}$ & $\begin{array}{l}\text { SNRB was highly } \\
\text { sensitive and spe- } \\
\text { cific, with a high } \\
\text { positive predictive } \\
\text { value for a good } \\
\text { surgical outcome. } \\
\end{array}$ \\
\hline $\begin{array}{l}\text { Krempen \& } \\
\text { Smith, } 1974 \\
\text { (169) } \\
\text { Observational } \\
\text { study }\end{array}$ & $\begin{array}{l}22 \text { patients } \\
\text { with sciatica }\end{array}$ & $\begin{array}{l}\text { Mechanical stimula- } \\
\text { tion and selective } \\
\text { nerve root injections }\end{array}$ & $\begin{array}{l}\text { Concordant pain } \\
\text { response to injection } \\
\text { and surgical outcome } \\
\text { in } 16 \text { of } 22 \text { patients }\end{array}$ & $\begin{array}{l}18 \text { patients had a positive result. } \\
\text { In the } 16 \text { patients that underwent } \\
\text { surgery after positive response to the } \\
\text { injection all improved with surgery } \\
\text { and had corresponding lesions at the } \\
\text { level suggested. }\end{array}$ & $\begin{array}{l}\text { SNRB is helpful di- } \\
\text { agnostically in sur- } \\
\text { gical planning, with } \\
100 \% \text { sensitivity. }\end{array}$ \\
\hline
\end{tabular}

$\mathrm{SNRB}=$ selective nerve root block; $\mathrm{MRI}$ = magnetic resonance imaging 


\begin{tabular}{|c|c|c|c|c|c|}
\hline Study/Year & Participants & Interventions(s) & Outcomes & Result(s) & Conclusion(s) \\
\hline $\begin{array}{l}\text { Tajima et al, } \\
1980(170) \\
\text { Prospective } \\
\text { case series }\end{array}$ & 106 patients & $\begin{array}{l}\text { Mechanical stimula- } \\
\text { tion with needle and } \\
\text { SNRB compared } \\
\text { with surgical } \\
\text { exploration }\end{array}$ & $\begin{array}{l}\text { Comparison of SNRB } \\
\text { response to imaging } \\
\text { and surgical findings }\end{array}$ & $\begin{array}{l}\text { In patients with positive SNRB, } \\
\text { imaging and surgical pathology were } \\
\text { concordant }\end{array}$ & $\begin{array}{l}\text { SNRB was helpful } \\
\text { diagnostically in } \\
\text { patients when me- } \\
\text { chanical stimulation } \\
\text { and SNRB were con- } \\
\text { cordant. The site of } \\
\text { entrapment was usu- } \\
\text { ally consistent with } \\
\text { surgical findings. }\end{array}$ \\
\hline $\begin{array}{l}\text { Haueisen et } \\
\text { al, } 1985 \text { (171) } \\
\text { Retrospective } \\
\text { study }\end{array}$ & $\begin{array}{l}105 \text { patients } \\
\text { with sciatica }\end{array}$ & $\begin{array}{l}\text { SNRB post laminec- } \\
\text { tomy with surgical } \\
\text { reexploration }\end{array}$ & $\begin{array}{l}\text { Comparison of } \\
\text { surgical findings } \\
\text { using SNRB versus } \\
\text { myelography and } \\
\text { electromyography. }\end{array}$ & $\begin{array}{l}\text { SNRB identified site of pathology in } \\
93 \% \text { of cases, vs. } 24 \% \text { and } 38 \% \text { with } \\
\text { myelography and electromyography, } \\
\text { respectively. }\end{array}$ & $\begin{array}{l}\text { SNRB more accurate } \\
\text { than myelography } \\
\text { and electromyogra- } \\
\text { phy in identifying a } \\
\text { symptomatic nerve } \\
\text { root. At } 1-5 \text { year } \\
\text { follow-up, } 49 \% \text { of } \\
\text { surgical patients had } \\
\text { minimal or no pain. }\end{array}$ \\
\hline $\begin{array}{l}\text { Castro \& van } \\
\text { Akkerveeken, } \\
1991(172) \\
\text { Observational } \\
\text { study }\end{array}$ & $\begin{array}{l}24 \text { patients } \\
\text { with lumbar } \\
\text { radiculitis }\end{array}$ & $\begin{array}{l}\text { Selective lumbar root } \\
\text { sheath infiltration. }\end{array}$ & $\begin{array}{l}\text { Assessment of the } \\
\text { diagnostic value of } \\
\text { SNRB. }\end{array}$ & $\begin{array}{l}\text { In } 24 \text { patients with classic disc } \\
\text { protrusion syndrome the sensitivity } \\
\text { was } 100 \% \text {. The predictive value in } \\
\text { patients with nerve root entrapment } \\
\text { due to degenerative narrowing of the } \\
\text { nerve root was } 70 \% \text { to } 80 \% \text {. }\end{array}$ & $\begin{array}{l}\text { Very high sensitivity } \\
\text { in disc protrusion, } \\
\text { and moderate pre- } \\
\text { dictive value with } \\
\text { foraminal stenosis. }\end{array}$ \\
\hline $\begin{array}{l}\text { Kikuchi et al, } \\
1984 \text { (173) } \\
\text { Anatomic } \\
\text { and clinical } \\
\text { studies of } \\
\text { radicular } \\
\text { symptoms - } \\
\text { an observa- } \\
\text { tional study }\end{array}$ & $\begin{array}{l}\text { Anatomic } \\
\text { study included } \\
\text { cadavers } \\
\text { of elderly } \\
\text { people with } \\
\text { dissection. } \\
\text { Clinical study } \\
\text { included } \\
\text { examination } \\
\text { of nerve root } \\
\text { infiltration on } \\
332 \text { cases with } \\
\text { assessment } \\
\text { of relation- } \\
\text { ship between } \\
\text { neurological } \\
\text { symptoms and } \\
\text { the morpho- } \\
\text { logic findings } \\
\text { of the contrast } \\
\text { study. }\end{array}$ & $\begin{array}{l}\text { Dissection of the } \\
\text { cadavers, SNRB }\end{array}$ & $\begin{array}{l}\text { Examination of nerve } \\
\text { root infiltration and } \\
\text { analysis of the relation } \\
\text { between neurologic } \\
\text { symptoms and the } \\
\text { morphologic findings } \\
\text { of the contrast study. }\end{array}$ & $\begin{array}{l}\text { Anatomic study showed sensory } \\
\text { rootlets had unusual segmental ar- } \\
\text { rangements in many cases, however, } \\
\text { no such arrangements were observed } \\
\text { with motor rootlets. In } 65 \text { of } 322 \text {, } \\
\text { neurologic findings did not corre- } \\
\text { spond with the results of the contrast } \\
\text { results. In these cases, nerve root } \\
\text { infiltration was a very useful ancillary } \\
\text { method of investigation. } \\
\text { In } 47 \text { of not-corresponding cases, } \\
\text { contrast studies showed abnormali- } \\
\text { ties at another level or multiple levels, } \\
\text { though the neurologic findings } \\
\text { were at a single level. In } 18 \text { cases, no } \\
\text { abnormality was found in contrast } \\
\text { studies in spite of existence of } \\
\text { neurologic symptoms. In the cases } \\
\text { of post surgery in } 13 \text { cases, the cases } \\
\text { associated with vascular insufficiency } \\
\text { ( } 2 \text { cases), spinal cord injury (one } \\
\text { case), perineural sacral cyst (one } \\
\text { case), and sclerotic pedicle of L4 (one } \\
\text { case), nerve root infiltration was very } \\
\text { useful in assessing the responsible } \\
\text { level. Analysis of radicular symp- } \\
\text { toms with nerve root infiltration } \\
\text { showed radicular pain or intermittent } \\
\text { claudication caused be degenerative } \\
\text { spondylolisthesis was abolished by } \\
\text { single nerve root infiltration in } 29 \\
\text { of } 38 \text { cases. In } 81 \text { of } 91 \text { cases, with } \\
\text { intermittent claudication, the pain } \\
\text { was abolished following single-nerve } \\
\text { root infiltration, and in only } 10 \text { cases } \\
\text { it was not effective. }\end{array}$ & $\begin{array}{l}\text { Authors in this } \\
\text { evaluation show } \\
\text { the value of SNRB } \\
\text { in patients without } \\
\text { correlation with } \\
\text { contrast study in a } \\
\text { pre-MRI era. }\end{array}$ \\
\hline
\end{tabular}


Table 5 (cont.). Characteristics of reported diagnostic accuracy studies.

\begin{tabular}{|c|c|c|c|c|c|}
\hline Study/Year & Participants & Interventions(s) & Outcomes & Result(s) & Conclusion(s) \\
\hline \begin{tabular}{|l|} 
Herron, 1989 \\
$(174)$ \\
Retrospective \\
study \\
\end{tabular} & $\begin{array}{l}215 \text { patients } \\
\text { with leg pain } \\
\text { ( } 78 \text { underwent } \\
\text { surgery) } \\
\end{array}$ & $\begin{array}{l}\text { SNRB prior to } \\
\text { surgery }\end{array}$ & $\begin{array}{l}\text { Comparison of } \\
\text { surgical findings and } \\
\text { outcomes }\end{array}$ & $\begin{array}{l}78 \text { patients underwent surgery. } 38 \\
\text { patients }(53 \%) \text { had a good surgical } \\
\text { result, } 16 \text { patients }(23 \%) \text { a fair result, } \\
\text { and } 17 \text { patients ( } 24 \%) \text { a poor result. }\end{array}$ & $\begin{array}{l}\text { SNRB helpful diag- } \\
\text { nostically in patients } \\
\text { without prior surgery. } \\
76 \% \text { sensitivity }\end{array}$ \\
\hline \begin{tabular}{|l} 
Yeom et al, \\
$2008(175)$ \\
Prospective \\
controlled \\
study
\end{tabular} & $\begin{array}{l}47 \text { consecu- } \\
\text { tive patients } \\
\text { with pure } \\
\text { radiculopathy }\end{array}$ & $\begin{array}{l}\text { SNRB were per- } \\
\text { formed at the symp- } \\
\text { tomatic level in } 47 \text {, } \\
\text { along with } 58 \text { blocks } \\
\text { performed at the } \\
\text { adjacent asymptom- } \\
\text { atic "control" level in } \\
47 \text { patients. }\end{array}$ & $\begin{array}{l}\text { Authors sought to } \\
\text { evaluate the accuracy } \\
\text { of diagnostic lumbar } \\
\text { SNRB and analyze } \\
\text { potential costs of inac- } \\
\text { curate results. They } \\
\text { defined a positive } \\
\text { block as a 70\% pain } \\
\text { relief. }\end{array}$ & $\begin{array}{l}\text { Diagnostic lumbar SNRB anesthetics } \\
\text { had a sensitivity of } 57 \% \text {, a specificity } \\
\text { of } 86 \% \text {, a positive predictive value of } \\
77 \% \text {, a negative predictive value of } \\
71 \% \text {, and an overall accuracy of } 73 \% \text {. } \\
\text { False-negatives were due to insufficient } \\
\text { infiltration, insufficient passage of } \\
\text { the injectate and epineural injections. } \\
\text { False-positive results were due to over- } \\
\text { flow of the injectate from the injected } \\
\text { asymptomatic level into either the } \\
\text { epidural space or symptomatic level. }\end{array}$ & $\begin{array}{l}\text { This study showed } \\
\text { moderate evidence } \\
\text { for accuracy of } \\
\text { diagnostic lumbar } \\
\text { selective nerve root } \\
\text { blocks. }\end{array}$ \\
\hline $\begin{array}{l}\text { Wolff et al, } \\
2001(182) \\
\text { Prospective } \\
\text { study }\end{array}$ & 29 patients & $\begin{array}{l}\text { Selective nerve root } \\
\text { injections }\end{array}$ & $\begin{array}{l}\text { Sensory testing after } \\
\text { SNRB }\end{array}$ & $\begin{array}{l}\text { Hypesthetic areas post-block were } \\
\text { variable and larger than paresthetic } \\
\text { areas pre-block. } \\
\text { Nerve root block patterns may differ } \\
\text { from classic dermatomal maps. }\end{array}$ & $\begin{array}{l}\text { This study illustrates } \\
\text { substantial variability } \\
\text { in segmental effects of } \\
\text { lumbosacral segmen- } \\
\text { tal nerve blocks with } \\
\text { local anesthetics.. }\end{array}$ \\
\hline $\begin{array}{l}\text { Stanley et al, } \\
1990 \text { (183) } \\
\text { Prospective } \\
\text { consecutive } \\
\text { series }\end{array}$ & $\begin{array}{l}50 \text { patients } \\
\text { with leg pain }\end{array}$ & $\begin{array}{l}\text { SNRB, CT and ra- } \\
\text { diculography results } \\
\text { compared with } \\
\text { surgery }\end{array}$ & $\begin{array}{l}\text { Comparison of SNRB } \\
\text { and radiculography to } \\
\text { surgical findings and } \\
\text { outcomes }\end{array}$ & $\begin{array}{l}\text { SNRB identified the symptomatic } \\
\text { level in } 18 \text { of } 19 \text { cases vs. } 14 \text { and } 12 \\
\text { that were identified with CT and } \\
\text { radiculography, respectively. }\end{array}$ & $\begin{array}{l}\text { SNRB may be } \\
\text { helpful in selecting } \\
\text { patients for surgery } \\
\text { with single level } \\
\text { involvement. }\end{array}$ \\
\hline \begin{tabular}{|l} 
Dooley et al, \\
$1988(185)$ \\
Retrospective \\
case series
\end{tabular} & $\begin{array}{l}62 \text { patients } \\
\text { with radicular } \\
\text { symptoms }\end{array}$ & $\begin{array}{l}\text { Mechanical stimula- } \\
\text { tion with needle and } \\
\text { SNRB compared } \\
\text { with surgery }\end{array}$ & $\begin{array}{l}\text { Comparison of } \\
\text { surgical outcome with } \\
\text { SNRB response }\end{array}$ & $\begin{array}{l}44 \text { patients had a positive result. } \\
\text { Surgery confirmed local pathology } \\
\text { in all cases. }\end{array}$ & $\begin{array}{l}\text { SNRB helpful } \\
\text { diagnostically when } \\
\text { mechanical stimula- } \\
\text { tion and SNRB are } \\
\text { concordant. }\end{array}$ \\
\hline $\begin{array}{l}\text { Schutz et al, } \\
1973(186) \\
\text { Retrospective } \\
\text { study }\end{array}$ & $\begin{array}{l}23 \text { patients } \\
\text { with sciatica }\end{array}$ & SNRB and surgery & $\begin{array}{l}\text { Comparison of SNRB } \\
\text { to surgical findings } \\
\text { and outcomes }\end{array}$ & $\begin{array}{l}15 \text { patients had positive test results } \\
\text { and underwent surgery. Surgical } \\
\text { findings agreed in } 13(87 \%) .18 \% \text { of } \\
\text { the tests failed because of failure to } \\
\text { stimulate the desired root. }\end{array}$ & $\begin{array}{l}\text { SNRB may be help- } \\
\text { ful in selection of } \\
\text { level of surgery. }\end{array}$ \\
\hline $\begin{array}{l}\text { Sasso et al, } \\
2005(187) \\
\begin{array}{l}\text { Observational } \\
\text { report }\end{array}\end{array}$ & $\begin{array}{l}101 \text { patients } \\
\text { with sciatica }\end{array}$ & $\begin{array}{l}\text { Selective nerve root } \\
\text { injections }\end{array}$ & $\begin{array}{l}\text { Comparison of surgi- } \\
\text { cal outcome between } \\
\text { MRI and selective } \\
\text { nerve root injection }\end{array}$ & $\begin{array}{l}91 \% \text { of patients with a positive selec- } \\
\text { tive nerve root injection had good } \\
\text { surgical outcomes, whereas } 60 \% \text { of } \\
\text { patients with a negative selective } \\
\text { nerve root injection had good out- } \\
\text { comes. Of the patients with a positive } \\
\text { MRI result, } 87 \% \text { had good surgical } \\
\text { outcomes, whereas a similar percent- } \\
\text { age of patients with a negative MRI, } \\
85 \% \text { had good surgical outcome. }\end{array}$ & $\begin{array}{l}\text { SNRB with negative } \\
\text { results are helpful in } \\
\text { predicting the ab- } \\
\text { sence of an offend- } \\
\text { ing lesion in cases } \\
\text { when MRI findings } \\
\text { were equivocal, } \\
\text { multilevel, and/or } \\
\text { do not agree with } \\
\text { patients' symptoms. }\end{array}$ \\
\hline \begin{tabular}{|l}
$\begin{array}{l}\text { Porter et al, } \\
1999(188)\end{array}$ \\
$\begin{array}{l}\text { Retrospective } \\
\text { evaluation }\end{array}$
\end{tabular} & $\begin{array}{l}56 \text { patients } \\
\text { with sciatica }\end{array}$ & SNRB & $\begin{array}{l}\text { To assess the results of } \\
\text { CT-directed perineu- } \\
\text { ral root infiltration }\end{array}$ & $\begin{array}{l}34 \text { patients had a diagnostic peri- } \\
\text { neural root infiltration to determine } \\
\text { whether surgery was appropriate. } \\
\text { Among } 18 \text { patients who had surgery, } \\
14 \text { had a successful, } 2 \text { a moderate, } \\
\text { and } 2 \text { a poor outcome. }\end{array}$ & $\begin{array}{l}\text { SNRB may be a } \\
\text { useful adjunct in } \\
\text { patients with abnor- } \\
\text { malities at multiple } \\
\text { levels and with poor } \\
\text { correlation with } \\
\text { clinical findings. }\end{array}$ \\
\hline
\end{tabular}

$\mathrm{SNRB}=$ selective nerve root block; $\mathrm{MRI}=$ magnetic resonance imaging 
Table 6. Clinical relevance of included studies.

\begin{tabular}{|c|c|c|c|c|c|c|}
\hline Manuscript Author(s) & $\begin{array}{l}\text { A) Patient } \\
\text { description }\end{array}$ & $\begin{array}{l}\text { B) Description of } \\
\text { interventions and } \\
\text { treatment settings }\end{array}$ & $\begin{array}{l}\text { C) Clinically } \\
\text { relevant } \\
\text { outcomes }\end{array}$ & $\begin{array}{l}\text { D) Clinical } \\
\text { importance }\end{array}$ & $\begin{array}{l}\text { E) Benefits } \\
\text { vs potential } \\
\text { harms }\end{array}$ & $\begin{array}{c}\text { Total } \\
\text { Criteria } \\
\text { Met }\end{array}$ \\
\hline Faraj and Mulholland, 2006 (78) & + & + & + & + & + & $5 / 5$ \\
\hline Wolff et al, 2006 (79) & + & + & + & + & + & $5 / 5$ \\
\hline Wolff et al, 2006 (80) & + & + & + & + & + & $5 / 5$ \\
\hline Vassiliev, 2007 (81) & + & + & + & + & + & $5 / 5$ \\
\hline Furman et al, 2008 (82) & + & + & + & + & + & $5 / 5$ \\
\hline Van Akkerveeken, 1993 (88) & + & + & + & + & + & $5 / 5$ \\
\hline Krempen \& Smith, 1974 (169) & + & + & + & + & + & $5 / 5$ \\
\hline Tajima et al, $1980(170)$ & + & + & + & + & + & $5 / 5$ \\
\hline Haueisen et al, 1985 (171) & + & + & + & + & + & $5 / 5$ \\
\hline $\begin{array}{l}\text { Castro \& van Akkerveeken, } 1991 \\
\text { (172) }\end{array}$ & + & + & + & + & + & $5 / 5$ \\
\hline Kikuchi et al, 1984 (173) & + & + & + & + & + & $5 / 5$ \\
\hline Herron, 1989 (174) & + & + & + & + & + & $5 / 5$ \\
\hline Yeom et al, 2008 (175) & + & + & + & + & + & $5 / 5$ \\
\hline Wolff et al, 2001 (182) & + & + & + & + & + & $5 / 5$ \\
\hline Stanley et al, 1990 (183) & + & + & + & + & + & $5 / 5$ \\
\hline Dooley et al, 1988 (185) & + & + & + & + & + & $5 / 5$ \\
\hline Schutz et al, 1973 (186) & + & + & + & + & + & $5 / 5$ \\
\hline Sasso et al, 2005 (187) & + & + & + & + & + & $5 / 5$ \\
\hline Porter et al, 1999 (188) & + & + & + & + & + & $5 / 5$ \\
\hline
\end{tabular}

211). None of the studies included in the diagnostic accuracy assessment reported any major complications (79-85,88,94-121,123,168-188).

In an academic physiatry practice over a 7-year period, McGrath et al (208) retrospectively evaluated the incidence and characteristics of complications from 3,964 lumbar transforaminal injections. They identified a lack of major complications and reported 103 minor complications, for an overall complication per injection rate of $2.4 \%$.

Karaman et al (129) assessed the complications of transforaminal lumbar epidural steroid injections. They reported a total of 1,305 episodes of lumbar transforaminal epidural steroid injections in 562 patients. The overall incidence of vascular penetration encountered was $7.4 \%$. However, major complications were not observed. The overall rate of minor complications was $11.5 \%$. In this study they reported an $8.7 \%$ incidence of vasovagal reactions.

Botwin et al (145) reported complications in 207 patients who underwent 322 transforaminal lumbar epidural steroid injections. Complications included transient headaches in $3.1 \%$, increased back pain in $2.4 \%$, increased leg pain in $0.6 \%$, facial flushing in $1.2 \%$, vasovagal reaction in $0.3 \%$, increased blood sugar in $0.3 \%$, and hypertension in $0.3 \%$. The incidence of minor complications was $9.6 \%$ per injection, with no major complications.

Furman et al (196) reported that among 761 transforaminal epidural steroid injections, the overall rate of intravascular injection was $11.2 \%$, with a higher rate $(21.3 \%)$ at the $\mathrm{S} 1$ level compared with those at lumbar levels $(8.1 \%)$.

Manchikanti et al (119) reported intravenous needle placement in $22 \%$ of transforaminal epidural injections. Other complications included back and leg pain during the injection in $43 \%$ and $22 \%$ of patients, respectively. Post-procedure complications were reported in $34 \%$ of patients, with soreness at the injection site occurring in $18 \%$, increased pain in $5 \%$, muscle spasms in $4 \%$, swelling in $4 \%$, headache in $3 \%$, minor bleeding in $2 \%$, dizziness in $1 \%$, nausea and vomiting in $1 \%$, fever in $1 \%$, numbness in $1 \%$, and voiding difficulty in $1 \%$.

Huston et al (197) reported no major complica- 
Pain Physician: April Special Issue 2013; 16:SE97-SE124

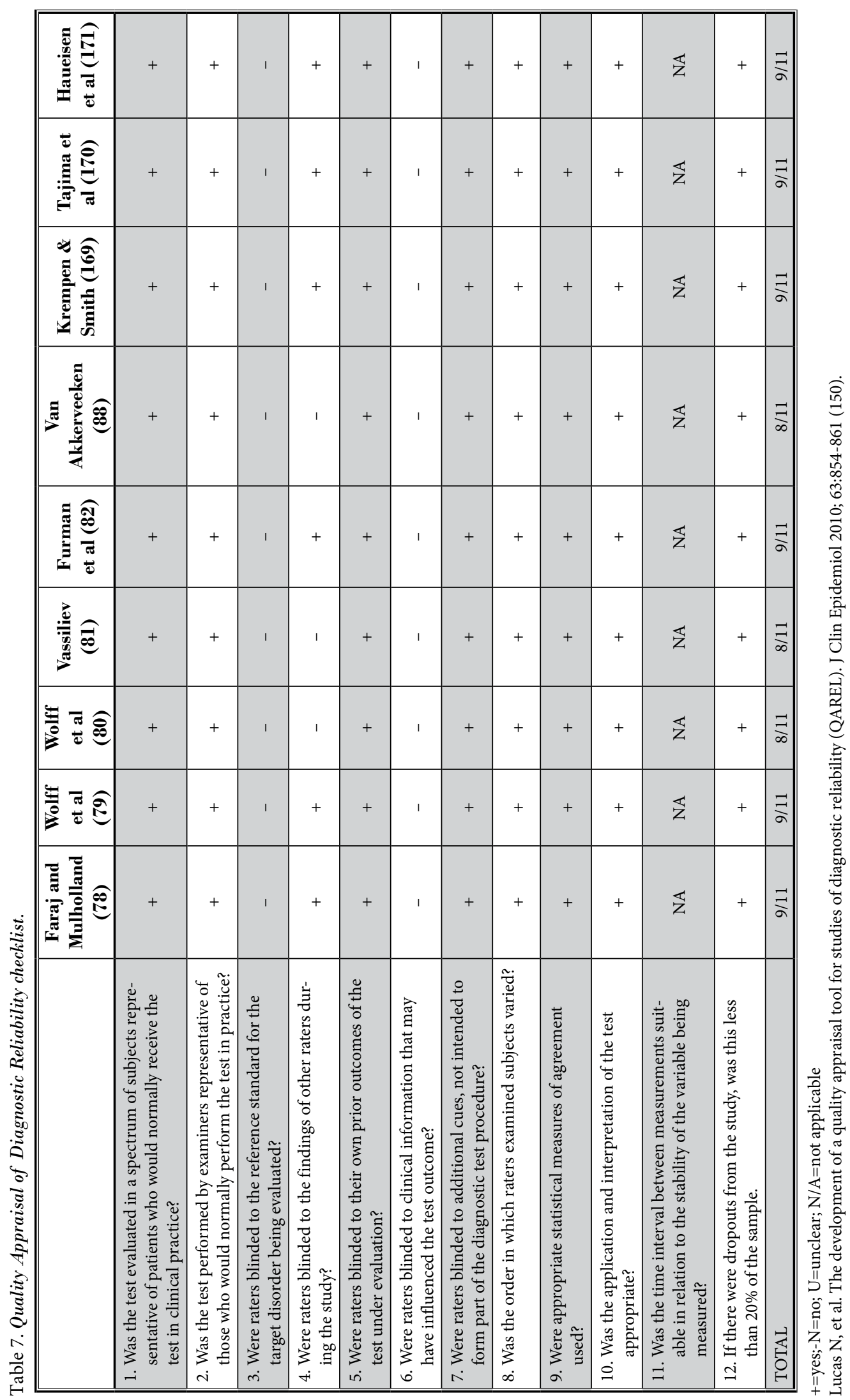




\begin{tabular}{|c|c|c|c|c|c|c|c|c|c|c|c|c|c|}
\hline 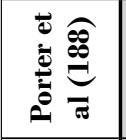 & + & + & 1 & + & + & 1 & 1 & + & 1 & + & $\mathbb{z}$ & + & 궁 \\
\hline  & + & + & 1 & + & + & 1 & 1 & + & + & + & $\mathbb{z}$ & + & $\vec{\infty}$ \\
\hline 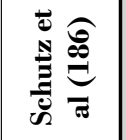 & + & + & 1 & + & + & 1 & 1 & + & 1 & + & $\mathbb{z}$ & + & 강 \\
\hline 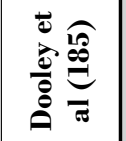 & + & + & 1 & + & + & 1 & + & + & + & + & $\overleftarrow{z}$ & + & 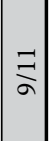 \\
\hline 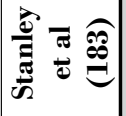 & + & + & 1 & + & + & 1 & + & + & + & + & $\mathbb{z}$ & + & $\vec{\Xi}$ \\
\hline 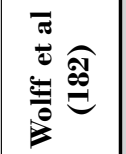 & + & + & 1 & + & + & 1 & + & + & + & + & $\mathbb{z}$ & + & इ \\
\hline 吾 & + & + & 1 & + & + & 1 & + & + & + & + & $\mathbb{z}$ & + & $\bar{z}$ \\
\hline 氖 & + & + & 1 & + & + & 1 & + & + & + & + & $\overleftrightarrow{z}$ & + & $\bar{z}$ \\
\hline 羿 & + & + & 1 & + & + & 1 & + & + & 1 & + & $\overleftrightarrow{z}$ & + & $\frac{\Xi}{\infty}$ \\
\hline  & + & + & 1 & + & + & 1 & + & + & 1 & + & $\mathbb{z}$ & + & $\underset{\infty}{-}$ \\
\hline & 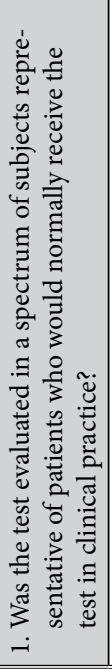 & 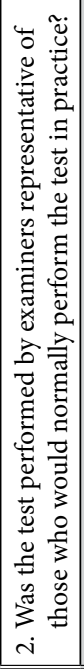 & 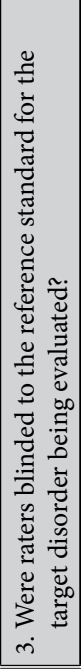 & 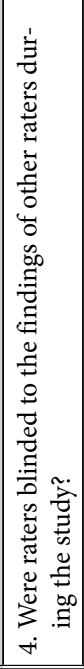 & 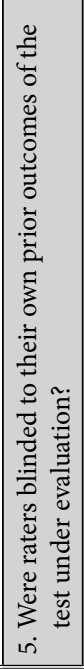 &  & 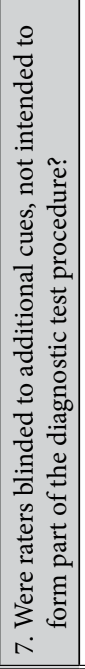 & 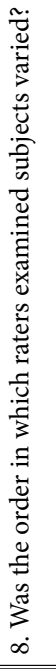 &  & 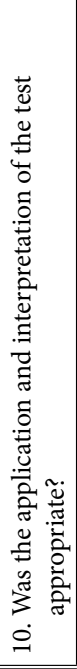 & 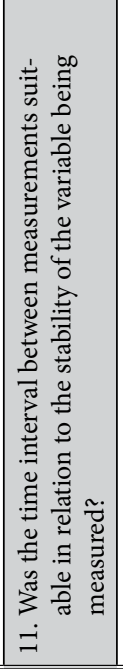 & 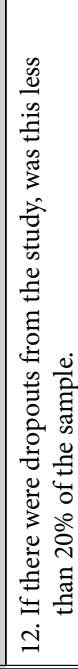 &  \\
\hline
\end{tabular}


Table 8. Summary of diagnostic accuracy studies.

\begin{tabular}{|l|c|c|c||}
\hline Manuscript Author(s) & $\begin{array}{c}\text { Methodological Quality } \\
\text { Scoring }\end{array}$ & Number of Subjects & Results \\
\hline Van Akkerveeken, 1993 (88) & $8 / 11$ & 46 & $\mathrm{P}$ \\
\hline Krempen \& Smith, 1974 (169) & $9 / 11$ & $\mathrm{P}$ \\
\hline Tajima et al, 1980 (170) & $9 / 11$ & $\mathrm{P}$ \\
\hline Haueisen et al, 1985 (171) & $9 / 11$ & $\mathrm{P}$ \\
\hline Castro \& van Akkerveeken, 1991 (172) & $8 / 11$ & $\mathrm{P}$ \\
\hline Kikuchi et al, 1984 (173) & $8 / 11$ & $\mathrm{P}$ \\
\hline Herron, 1989 (174) & $9 / 11$ & $\mathrm{P}$ \\
\hline Yeom et al, 2008 (175) & $9 / 11$ & $\mathrm{~N}$ \\
\hline Wolff et al, 2001 (182) & $9 / 11$ & 78 & $\mathrm{~N}$ \\
\hline Stanley et al, 1990 (183) & $9 / 11$ & $\mathrm{P}$ \\
\hline Dooley et al, 1988 (185) & $9 / 11$ & 29 & $\mathrm{P}$ \\
\hline Schutz et al, 1973 (186) & $7 / 11$ & 50 & $\mathrm{P}$ \\
\hline Sasso et al, 2005 (187) & $8 / 11$ & $\mathrm{~N}$ \\
\hline Porter et al, 1999 (188) & $7 / 11$ & $\mathrm{~N}$ \\
\hline
\end{tabular}

$\mathrm{P}=$ positive; $\mathrm{N}=$ negative

tions, with $91 \%$ of patients experiencing no side effects during cervical and lumbar selective nerve root blocks. The most common side effect was increased pain at the injection site, which was observed after $17.1 \%$ of lumbar injections.

In their review of complications and pitfalls of lumbar interlaminar and transforaminal epidural injections, Goodman et al (207) concluded that complications from lumbar epidural injections are extremely rare. Most, if not all, complications can be avoided by careful technique with accurate needle placement, sterile precautions, and a thorough understanding of the relevant anatomy and contrast patterns on fluoroscopic imaging.

However, complications from transforaminal injections have been reported to include spinal cord injury and infarction, resulting in paraplegia $(127,131)$. Side effects related to the administration of steroids are generally attributed either to chemistry or pharmacology (198). The major theoretical complications of corticosteroid administration include the suppression of pituitary adrenal axis, hyperadrenocorticism, Cushing syndrome, osteoporosis, avascular necrosis, steroid myopathy, epidural lipomatosis, weight gain, fluid retention, and hyperglycemia (198). Radiation exposure is also a potential problem, with resultant damage to the eyes, skin, and gonads $(205,210)$.

\subsection{Discussion}

This systematic review evaluating the diagnostic accuracy of selective nerve root blocks found limited efficacy in identifying lumbar radicular pain when radiologic abnormalities are not correlated with clinical symptomatology. Diagnostic selective nerve root blocks have often been used to confirm the pain-generating nerve root. Despite their widespread use, the reported accuracy of these blocks for determining a symptomatic level varies from $31 \%$ to $100 \%$. In addition to the wide range in accuracy, most of the studies have been retrospective in nature, have had a small sample size, and have failed to describe their methodologies in detail (211). In addition, in all the studies on the topic to date, the definition of a positive or negative result based on the degree of pain relief has either been arbitrarily set between $50 \%$ and $100 \%$ or has not been clearly defined. A majority of studies have analyzed the sensitivity, specificity, accuracy, and predictive values because they focus on the results of diagnostic selective nerve root block on the presumed lesion level alone, and many employed "control" injections at "unaffected roots." Consequently, the diagnostic accuracy of selective nerve root blocks continues to be questioned $(52,211-213)$.

Only one controlled blinded study by Yeom et al 
(175) assessed the control root levels and defined a positive block as $>70 \%$ pain relief, as determined by receiver-operator characteristic (ROC) analysis. They arrived at a sensitivity of $57 \%$, a specificity of $86 \%$, an accuracy of $73 \%$, a positive predictive value of $77 \%$, and a negative predictive value of $71 \%$. They confirmed the findings of other investigators that false-positives were frequently the result of overflow of the injectate from the injected level into either the epidural space or to another level that was symptomatic. They demonstrated that false-negative blocks were due to insufficient infiltration, insufficient spread of injectate, and intra-epineural injections. Multiple other studies have demonstrated difficulty in localizing injections without inadvertent spread to the epidural space or another level, even when low volumes (i.e. $0.5 \mathrm{~mL}$ ) are employed $(81,82)$. In the study by Yeom et al $(175)$, the evidence was shown to be only moderate, and the diagnostic value was relatively low compared with previous reports $(88,169,171,174,183,185-188,214,215)$ most of which did not attempt to quantify falsepositive results. In this and other studies, significant false-negative blocks occur concomitantly with falsepositives. Almost all studies were characterized by significant limitations.

Overall, this systematic review suggests that the diagnostic value of selective nerve root blocks in the lumbar spine is not high, confirming the hypothesis of Shah (62). The value may be improved by using a nerve stimulator and utilizing a meticulous injection technique with extremely low volume; however, this contention is based on only one high quality study (175).

A diagnostic test is useful only to the extent that it distinguishes between the reference condition and other disorders that might otherwise be misdiagnosed. Many tests can distinguish healthy persons from severely affected ones or those with appropriate abnormalities on radiologic investigations, but being able to differentiate these 2 types of patients reveals very little about the clinical utility of a test. The true pragmatic value of a test can only be established in a study that closely resembles clinical practice. Studies evaluating the accuracy of facet joint nerve blocks have provided us with reliability and validity data for controlled diagnostic blocks, with a criterion standard of $>75 \%$ pain relief during the performance of previously painful movements following dual blocks being designated as accurate (69-71). However, extrapolating these criteria to selective nerve root blocks may not be justified.

A systematic review is defined as, "the application of scientific strategies that limit bias by the systematic assembly, critical appraisal, and synthesis of all relevant studies on a specific topic" $(216,217)$. Systematic reviews are labor intensive and require expertise in both the subject matter and review methods. Thus, expertise in only area is not sufficient, and may lead to inaccurate conclusions and inappropriate recommendations (218-222). This systematic review provides not only crucial expertise in the subject matter, but synthesizes that expertise via the application of stringent methodology. A systematic review differs from a narrative review in that the former attempts to minimize bias by the comprehensiveness and reproducibility of its search and selection strategies, and through the transparent grading of methodological quality (218-222). In this systematic review, we attempted to answer specific clinical questions in depth - how accurate and valid are diagnostic selective nerve root blocks?

The Institute of Medicine (IOM) standards for systematic reviews (223) described 4 major standards:

1) Standards for initiating the systematic review;

2) Standards for finding and assessing individual studies;

3) Standards for synthesizing the body of evidence; and

4) Standards for reporting systematic reviews.

The IOM also described multiple challenges and methods to overcome these challenges when developing guidelines (224). The IOM notes that the literature assessing the best methods for guideline development have evolved dramatically in the 20 years since the IOM's first report on the subject (225).

The outcomes of most therapeutic options depend on proper diagnosis. Selective nerve root blocks may be used as a diagnostic entity prior to surgical interventions. If one operates under the premises that a treatment (i.e. decompression surgery) is more efficacious when performed on the correct level on an appropriate patient than it is when performed on the wrong level, then one can prove through deductive reasoning - i.e. without virtue of a clinical trial - that identifying the affected spinal level improves treatment outcomes. Currently, there are numerous available modalities for the diagnosis and management of low back pain, with escalating costs and untoward effects that can adversely impact health care resources (226-270). Selective nerve root blocks can encompass many of the disadvantages of a diagnostic test. One of the major challenges is that, unlike facet joint nerve blocks, sacroiliac joint nerve blocks, and even discography, selective nerve 
root blocks are not generally performed as dual blocks in a controlled environment, which can serve to reduce false-positive results (66-68). Because of this, and the fact that no reference standard such as a tissue or biopsy diagnosis can confirm the results, the validity of selective nerve root blocks in the diagnosis of lumbosacral radiculitis has not been established. In addition, the effects that potential confounding factors, such as psychological disorders, opioid usage, age, and obesity, have on the results of selective nerve root blocks, have not been studied.

Not only has the construct validity of selective nerve root blocks been questioned, but also the face validity. Local anesthetic injected accurately onto the targeted nerve root(s) should theoretically alleviate pain only in the distribution of the nerve(s). Yet, in addition to there being significant dermatomal overlap between adjacent nerve roots, even when the procedure is performed with low volumes under fluoroscopic visualization, the injectate frequently extravasates to adjacent potential pain generators, which can undermine face validity.

Despite these obstacles, there is evidence that does support the validity of selective nerve root blocks. In an early study performed in 105 patients with radicular pain, $57 \%$ of whom had undergone previous surgery, Haueisen et al (171) compared the diagnostic accuracy of spinal nerve root injections with lidocaine to myelography and electromyography with regard to surgical findings and treatment outcomes. Among the 55 patients who underwent surgical exploration, selective nerve root injections were accurate in identifying the surgical pathology in $93 \%$ of patients, which favorably compared to accuracy rates of $24 \%$ for myelography, $58 \%$ for discography, and 38\% for electrodiagnostic studies. At follow-up periods ranging from 1-5 years, $49 \%$ of patients had minimal or no pain vs. $16 \%$ of patients who were treated non-operatively. The authors concluded that in patients with surgically altered anatomy, selective nerve root blocks are helpful in making an accurate diagnosis.

Herron (174) examined the response to selective nerve root blocks as a means to confirm the spinal origin of pain. The surgical outcomes were as expected, with the best outcomes noted for lumbar disc herniation ( $83 \%$ good outcomes) and spinal stenosis (55\% good results), while those with a history of prior surgery experienced the poorest results $(29 \%$ good outcomes). The response to injection was helpful in narrowing potential surgical patients from 215 to 71 patients.
In a 1980 study, Tajima et al (170) descriptively compared mechanical stimulation and anesthetic response to nerve root injections against myelography. Comparison to normal dye patterns in reference patients and cadavers was also used to clarify the role of radiculography as a diagnostic imaging tool. The disorders studied were diverse, but selective nerve root block deemed helpful in determining the painful segment in the majority of patients, with corresponding abnormalities found on surgical repair. The authors also felt it was helpful in limiting surgical decompression to the area of primary pain generation.

A retrospective study by Schutz et al (186) reported on the accuracy of selective nerve root blocks in 23 patients. Among the 15 patients in whom an operation was performed at the level indicated by the selective nerve root block, $13(87 \%)$ had findings that correlated with the results of the diagnostic block. Eighteen percent of blocks failed because of either intolerable pain during the procedure or failure to stimulate the desired root, most often at S1.

With respect to accuracy, it is generally measured in terms of sensitivity and specificity. Specificity is a relative measure of the prevalence of false-positives, whereas sensitivity is the relative prevalence of falsenegative results. There are several factors that can lead to a false-positive selective nerve root block despite precautions, including the close proximity of numerous potential pain-generating structures that can be anesthetized by the aberrant extravasation of local anesthetic. Consequently, selective nerve root blocks are considered to have a higher degree of sensitivity than specificity.

The sensitivity and specificity of diagnostic selective nerve root blocks range from $45 \%$ to $100 \%$ $(88,123,169,171,175,183-186)$. Schutz et al (186) reported finding a corroborative lesion at the time of surgery in $87 \%$ of patients with a positive diagnostic block. Krempen and Smith (169) reported $100 \%$ surgical confirmation following a positive block. Dooley et al (185) reported 3 out of 51 blocks to be false-positive, for a specificity of $94 \%$ while Stanley et al (183) reported $95 \%$ specificity. Van Akkerveeken (88) attempted to establish the diagnostic value of selective nerve root injections by comparing 37 patients with confirmed lumbar radiculopathy to 9 patients with pain due to metastases. The authors found the sensitivity for pain neuropathic spinal to be $100 \%$, with the specificity, as determined by comparison to a normal level on imaging, around $90 \%$. When calculating the positive predic- 
tive value, there was a $95 \%$ chance that patients with a positive selective nerve block would experience a good surgical outcome. If all patients who declined surgery were included in the analysis as surgical failures, the positive predictive value declined to $70 \%$. Other reported specificities are $96 \%$ by Anderberg et al (184), $93 \%$ by Haueisen et al (171), and $85 \%$ by Dooley et al (185).

In a small prospective study comparing the specificity of $0.6 \mathrm{~mL}, 1.1 \mathrm{~mL}$ and $1.7 \mathrm{~mL}$, Anderberg et al (123) found that the use of lower volumes was associated with comparable "sensitivity," but increased specificity. A well-controlled prospective study by Yeom et al (175) showed a sensitivity of $57 \%$, a specificity of $86 \%$, a positive predictive value of $77 \%$, and a negative predictive value of $71 \%$ based on $70 \%$ pain relief determined by receiver-operator characteristic analysis. Overall, the accuracy was determined to be $73 \%$. In view of the findings by North et al (215) that showed that all uncontrolled nerve blocks are non-specific, the high reported levels of sensitivity and specificity need to be confirmed in controlled studies.

The injection of local anesthetics may result in extravasation beyond the target nerve root to surrounding structures, including adjacent dorsal rami, spinal or sinuvertebral nerves, muscles, and even facet joints, causing a false-positive result $(80-82,122,123)$. For CT guided lumbar selective nerve root blocks, Castro et al (122) demonstrated epidural spread in $48 \%$ of cases, and diffusion to an adjacent nerve root in $27 \%$, even with their lowest injected volume (i.e., $0.5 \mathrm{~mL}$ ). Wolff et al (182) utilized a combination of fluoroscopy and electrostimulation to perform the selective nerve root blocks, but still found epidural spread in $47 \%$ of L4, and $28 \%$ of $\mathrm{L} 5$ blocks, with spread to adjacent nerve roots occurring in $5 \%$ of procedures. Anatomical variations, such as nerve root abnormalities, were found in $14 \%$ of individuals (271). A furcal nerve usually arises from the L4 root level and contributes to both the lumbar and sacral plexuses. Neurologic symptoms, suggestive of 2 root involvement, frequently result from furcal nerve compression (272). Pain relief resulting from blockade of a spinal nerve cannot be used to distinguish between pathology of the nerve itself, or pain transmitted through that nerve from distal sites. Ongoing sciatic pain can be relieved by sciatic nerve block, distal or collateral to any pathology $(273,274)$. Distal referred pain in response to paraspinal noxious stimuli (i.e. hypertonic saline) can be prevented by peripheral somatic blockade in the area of referral (275). Finally, pain is always subjective, and may be influenced by psychological, social, financial and legal factors, as well as by concurrent therapies. Because the placebo effect has been shown to be proportional to the invasiveness of a procedure $(276,277)$, performing injections on 2 or more occasions may minimize this confounding effect.

In summary, the role of selective nerve root blocks in providing an accurate diagnosis prior to surgical intervention is limited, but still emerging.

\subsection{Conclusion}

This systematic review shows limited evidence for selective nerve root blocks as a diagnostic test for equivocal radicular pain.

\section{Acknowledgments}

The authors also wish to thank Vidyasagar Pampati, MSc, for statistical assistance; Sekar Edem for assistance in the search of the literature; Alvaro F. Gómez, MA, and Laurie Swick, BS, for manuscript review; and Tonie M. Hatton and Diane E. Neihoff, transcriptionists, for their assistance in preparation of this manuscript. The authors thank Pain Physician for permission to reproduce Datta et al's manuscript from 2007 (51). We would like to thank the editorial board of Pain Physician for review and criticism in improving the manuscript.

\section{Author Affiliations}

Dr. Datta is Medical Director, Laser Spine \& Pain Institute, New York, NY, and Professorial Lecturer, Mount Sinai School of Medicine, Department of Anesthesiology, New York, NY.

Dr. Manchikanti is Medical Director of the Pain Management Center of Paducah, Paducah, KY and Clinical Professor, Anesthesiology and Perioperative Medicine, University of Louisville, Louisville, KY.

Dr. Falco is Medical Director of Mid Atlantic Spine \& Pain Physicians, Newark, DE; Director, Pain Medicine Fellowship Program, Temple University Hospital, Philadelphia, PA and Associate Professor, Department of PM\&R, Temple University Medical School, Philadelphia, PA.

Dr. Calodney is Medical Director, Texas Pain, The Texas Spine and Joint Hospital, Tyler, TX.

Dr. Atluri is Medical Director, Tri-State Spine Care Institute, Cincinnati, $\mathrm{OH}$.

Dr. Benyamin is the Medical Director, Millennium Pain Center, Bloomington, IL, and Clinical Assistant Professor of Surgery, College of Medicine, University of IIlinois, Urbana-Champaign, IL. 
Dr. Buenaventura is Medical Director, Pain Relief of Dayton, Centerville, $\mathrm{OH}$, and Clinical Associate Professor, Department of Surgery, Wright State University School of Medicine, Dayton, $\mathrm{OH}$.

Dr. Cohen is Professor, Department of Anesthesiology and Critical Care Medicine, Pain Management Division, Johns Hopkins School of Medicine, Baltimore, MD and Professor, Department of Anesthesiology, Uniformed Services University of the Health Sciences, Bethesda, MD.

\section{Conflict of Interest:}

Dr. Calodney is a consultant for Stryker, Inc.; Medtronic, Inc.; and Nimbus Concepts.

Dr. Datta receives research support from Sucampo
Pharmaceuticals and an honorarium from Smith and Nephew.

Dr. Falco is a Consultant for St. Jude Medical Inc. and Joimax Inc.

Dr. Benyamin is a consultant with Bioness and Nevro; serves on the advisory boards of Vertos Medical and Nuvo Pharma; teaches/lectures for Vertos Medical, Boston Scientific, Neurotherm, and Bioness; and receives research/grants from Alfred Mann Foundation, Teknon Foundation, Spinal Restoration, Inc., Bioness, Boston Scientific, Vertos Medical, Medtronic, Kimberly Clarke, Epimed, BioDelivery Sciences International, Inc., Theravance, Mundipharma Research, Cephalon/Teva, AstraZeneca, and Purdue Pharma, LP.

\section{References}

1. Weinstein JN, Tosteson TD, Lurie JD, Tosteson AN, Hanscom B, Skinner JS, Abdu WA, Hilibrand AS, Boden SD, Deyo RA. Surgical vs nonoperative treatment for lumbar disk herniation: The Spine Patient Outcomes Research Trial (SPORT): A randomized trial. JAMA 2006; 296:2441-2450.

2. Deyo RA, Weinstein JN. Low back pain. $N$ Engl J Med 2001; 344:363-370.

3. Weinstein JN, Bronner KK, Morgan TS, Wennberg JE. Trends and geographic variations in major surgery for degenerative diseases of the hip, knee, and spine. Health Aff (Millwood) 2004; (suppl Web exclusive):var81-var89.

4. Radcliff K, Hilibrand A, Lurie JD, Tosteson TD, Delasotta L, Rihn J, Zhao W, Vaccaro A, Albert TJ, Weinstein JN. The impact of epidural steroid injections on the outcomes of patients treated for lumbar disc herniation: A subgroup analysis of the SPORT trial. J Bone Joint Surg Am 2012; 94:1353-1358.

5. Benyamin RM, Manchikanti L, Parr AT, Diwan SA, Singh V, Falco FJE, Datta S, Abdi S, Hirsch JA. The effectiveness of lumbar interlaminar epidural injections in managing chronic low back and lower extremity pain. Pain Physician 2012; 15:E363-E404.

6. Parr AT, Manchikanti L, Hameed $\mathrm{H}$, Conn A, Manchikanti KN, Benyamin RM, Diwan S, Singh V, Abdi S. Caudal epidural injections in the management of chronic low back pain: A systematic appraisal of the literature. Pain Physician 2012; 15:E159-E198.
7. Manchikanti L, Buenaventura RM, Manchikanti KN, Ruan X, Gupta S, Smith HS, Christo PJ, Ward SP. Effectiveness of therapeutic lumbar transforaminal epidural steroid injections in managing lumbar spinal pain. Pain Physician 2012; 15:E199-E245.

8. Benyamin RM, Wang VC, Vallejo $R$, Singh V, Helm S II. A systematic evaluation of thoracic interlaminar epidural injections. Pain Physician 2012; 15:E497E514.

9. Diwan SA, Manchikant L, Benyamin RM, Bryce DA, Geffert S, Hameed $H$, Sharma ML, Abdi S, Falco FJE. Effectiveness of cervical epidural injections in the management of chronic neck and upper extremity pain. Pain Physician 2012; 15:E405-E434.

10. Manchikanti L, Singh V, Cash KA, Pampati V, Damron KS, Boswell MV. A randomized, controlled, double-blind trial of fluoroscopic caudal epidural injections in the treatment of lumbar disc herniation and radiculitis. Spine (Phila Pa 1976) 2011; 36:1897-1905.

11. Manchikanti L, Singh V, Cash KA, Pampati V, Damron KS, Boswell MV. Effect of fluoroscopically guided caudal epidural steroid or local anesthetic injections in the treatment of lumbar disc herniation and radiculitis: $A$ randomized, controlled, double blind trial with a two-year follow-up. Pain Physician 2012; 15:273-286.

12. Manchikanti L, Cash KA, McManus CD, Pampati V, Fellows B. Fluoroscopic caudal epidural injections with or with- out steroids in managing pain of lumbar spinal stenosis: One year results of randomized, double-blind, active-controlled trial. J Spinal Disord Tech 2012; 25:226-234.

13. Manchikanti L, Cash KA, McManus CD, Pampati V, Fellows B. Results of 2-year follow-up of a randomized, doubleblind, controlled trial of fluoroscopic caudal epidural injections in central spinal stenosis. Pain Physician 2012; 15:371384 .

14. Manchikanti L, Singh V, Cash KA, Pampati V, Datta S. Fluoroscopic caudal epidural injections in managing post lumbar surgery syndrome: Two-year results of a randomized, double-blind, activecontrol trial. Int J Med Sci 2012; 9:582591.

15. Manchikanti L, Cash KA, McManus CD, Pampati V. Fluoroscopic caudal epidural injections in managing chronic axial low back pain without disc herniation, radiculitis or facet joint pain. J Pain Res 2012; 5:381-390.

16. Manchikanti L, Cash KA, McManus CD, Pampati V, Smith HS. One year results of a randomized, double-blind, active controlled trial of fluoroscopic caudal epidural injections with or without steroids in managing chronic discogenic low back pain without disc herniation or radiculitis. Pain Physician 2011; 14:25-36.

17. Manchikanti L, Singh V, Cash KA, Pampati V, Falco FJE. The role of fluoroscopic interlaminar epidural injections in managing chronic pain of lumbar disc herniation or radiculitis: A randomized, dou- 
ble-blind trial. Pain Pract 2012 Dec. 27. [Epub ahead of print].

18. Manchikanti L, Cash KA, McManus CD, Pampati V, Benyamin R. Fluoroscopic lumbar interlaminar epidural injections in managing chronic lumbar axial or discogenic pain. J Pain Res 2012; 5:301311.

19. Manchikanti L, Cash KA, McManus CD, Damron KS, Pampati V, Falco FJE. Lumbar interlaminar epidural injections in central spinal stenosis: Preliminary results of a randomized, double-blind, active control trial. Pain Physician 2012; 15:51-63.

20. Manchikanti L, Cash KA, Pampati V, Wargo BW, Malla Y. Management of chronic pain of cervical disc herniation and radiculitis with fluoroscopic cervical interlaminar epidural injections. Int J Med Sci 2012; 9:424-434.

21. Manchikanti L, Cash KA, Pampati V, Malla Y. Fluoroscopic cervical epidural injections in chronic axial or disc-related neck pain without disc herniation, facet joint pain, or radiculitis. J Pain Res 2012; 5:227-236.

22. Manchikanti L, Malla Y, Cash KA, McManus $C D$, Pampati V. Fluoroscopic epidural injections in cervical spinal stenosis: Preliminary results of a randomized, double-blind, active control trial. Pain Physician 2012; 15:E59-E70.

23. Manchikanti L, Malla Y, Cash KA, McManus CD, Pampati V. Fluoroscopic cervical interlaminar epidural injections in managing chronic pain of cervical postsurgery syndrome: Preliminary results of a randomized, double-blind active control trial. Pain Physician 2012; 15:1326.

24. Cohen SP, White RL, Kurihara C, Larkin TM, Chang A, Griffith SR, Gilligan C, Larkin R, Morlando B, Pasquina PF, Yaksh TL, Nguyen C. Epidural steroids, etanercept, or saline in subacute sciatica: A multicenter, randomized trial. Ann Intern Med 2012; 156:551-559.

25. Kloth DS, Calodney AK, Derby R, Lagattuta FP, O'Neill C, Yurth E, Miller LE, Block JE. Improving the safety of transforaminal epidural steroid injections in the treatment of cervical radiculopathy. Pain Physician 2011; 14:285-293.

26. Zhu J, Falco FJ, Formoso F, Onyewu O, Irwin FL. Alternative approach for lumbar transforaminal epidural steroid injections. Pain Physician 2011; 14:331-341.

27. Park $\mathrm{CH}$, Lee SH, Park HS. Lumbar retrodiscal versus post-ganglionic trans- foraminal epidural steroid injection for the treatment of lumbar intervertebral disc herniations. Pain Physician 2011; 14:353-360.

28. Kang SS, Hwang BM, Son HJ, Cheong IY, Lee SJ, Lee SH, Chung TY. The dosages of corticosteroid in transforaminal epidural steroid injections for lumbar radicular pain due to a herniated disc. Pain Physician 2011; 14:361-370.

29. Park $\mathrm{CH}$, Lee $\mathrm{SH}$, Jung JY. Dural sac cross-sectional area does not correlate with efficacy of percutaneous adhesiolysis in single level lumbar spinal stenosis. Pain Physician 2011; 14:377-382.

30. Amr YM. Effect of addition of epidural ketamine to steroid in lumbar radiculitis: One-year follow-up. Pain Physician 2011; 14:475-481.

31. Gharibo CG, Varlotta GP, Rhame EE, Liu EC, Bendo JA, Perloff MD. Interlaminar versus transforaminal epidural steroids for the treatment of subacute lumbar radicular pain: a randomized, blinded, prospective outcome study. Pain Physician 2011; 14:499-511.

32. Lee JH, Lee SH. Clinical effectiveness of percutaneous adhesiolysis using Navicath for the management of chronic pain due to lumbosacral disc herniation. Pain Physician 2012; 15:213-221.

33. Lee MG, Huh BK, Choi SS, Lee DK, Lim BG, Lee M. The effect of epidural resiniferatoxin in the neuropathic pain rat model. Pain Physician 2012; 5:287-296.

34. Kim HJ, Park JH, Shin KM, Kang SS, Kim IS, Hong SJ, Song CK, Park JC, Yeom JS. The efficacy of transforaminal epidural steroid injection by the conventional technique in far-lateral herniation of lumbar disc. Pain Physician 2012; 15:415420.

35. Beall DP, Deer TR, Wilsey JT, Walsh AJ, Block JH, McKay WF, Zanella JM. Tissue distribution of clonidine following intraforaminal implantation of biodegradable pellets: Potential alternative to epidural steroid for radiculopathy. Pain Physician 2012; 15:E701-E710.

36. Chang-Chien GC, Candido KD, Knezevic NN. Digital subtraction angiography does not reliably prevent paraplegia associated with lumbar transforaminal epidural steroid injection. Pain Physician 2012; 15:515-523.

37. Chou R, Huffman L. Guideline for the Evaluation and Management of Low Back Pain: Evidence Review. American Pain Society, Glenview, IL, 2009.

www.americanpainsociety.org/uploads/
pdfs/LBPEvidRev.pdf

38. Manchikanti L, Datta S, Gupta S, Munglani R, Bryce DA, Ward SP, Benyamin RM, Sharma ML, Helm II S, Fellows B, Hirsch JA. A critical review of the American Pain Society clinical practice guidelines for interventional techniques: Part 2. Therapeutic interventions. Pain Physician 2010; 13:E215-E264.

39. Dashfield AK, Taylor MB, Cleaver JS, Farrow D. Comparison of caudal steroid epidural with targeted steroid placement during spinal endoscopy for chronic sciatica: A prospective, randomized, double-blind trial. Br J Anaesth 2005; 94:514-559.

40. Ackerman WE 3 rd, Ahmad M. The efficacy of lumbar epidural steroid injections in patients with lumbar disc herniations. Anesth Analg 2007; 104:1217-1222.

41. Wewalka M, Abdelrahimsai A, Wiesinger GF, Uher EM. CT-guided transforaminal epidural injections with local anesthetic, steroid, and tramadol for the treatment of persistent lumbar radicular pain. Pain Physician 2012; 15:153-159.

42. Jensen MC, Brant-Zawadzki MN, Obuchowski N, Modic MT, Malkasian D, Ross JS. Magnetic resonance imaging of the lumbar spine in people without back pain. N Engl J Med 1994; 331:69-73.

43. Zobel BB, Vadalà G, Del Vescovo R, Battisti S, Martina FM, Stellato L, Leoncini E, Borthakur A, Denaro V. T1 1 magnetic resonance imaging quantification of early lumbar intervertebral disc degeneration in healthy young adults. Spine (Phila Pa 1976) 2012; 37:1224-1230.

44. Saal JA, Saal JS. Nonoperative treatment of herniated lumbar intervertebral disc with radiculopathy. Spine (Phila Pa 1976) 1989; 14:431-437.

45. Haugen AJ, Brox JI, Grøvle L, Keller A, Natvig B, Soldal D, Grotle M. Prognostic factors for non-success in patients with sciatica and disc herniation. BMC Musculoskelet Disord 2012; 13:183.

46. Sutheerayongprasert C, Paiboonsirijit $\mathrm{S}$, Kuansongtham $\mathrm{V}$, Anuraklekha S, Hiranyasthiti N, Neti S. Factors predicting failure of conservative treatment in lumbar-disc herniation. J Med Assoc Thai 2012; 95:674-680.

47. Manchikanti L, Boswell MV, Singh $V$, Benyamin RM, Fellows B, Abdi S, Buenaventura RM, Conn A, Datta S, Derby R, Falco FJE, Erhart S, Diwan S, Hayek SM, Helm S, Parr AT, Schultz DM, Smith HS, Wolfer LR, Hirsch JA. Comprehensive evidence-based guidelines for in- 
terventional techniques in the management of chronic spinal pain. Pain Physician 2009; 12:699-802.

48. Bogduk N, McGuirk B. Causes and sources of chronic low back pain. In: Bogduk N, McGuirk B (eds). Medical Management of Acute and Chronic Low Back Pain, An Evidence-Based Approach. Pain Research and Clinical Management. Vol 13. Elsevier Science BV, Amsterdam, 2002, 115-126.

49. Boden SD, Davis DO, Dina TS, Patronas $\mathrm{NJ}$, Wiesel SW. Abnormal magnetic-resonance scans of the lumbar spine in asymptomatic subjects: A prospective investigation. J Bone Joint Surg Am 1990; 72:403-408.

50. Manchikanti L, Hirsch JA, Datta S, Falco FJE. Low back and lumbar radicular pain. In: Manchikanti L, Christo PJ, Trescot AM, Falco FJE (eds). Clinical Aspects of Pain Medicine and Interventional Pain Management: A Comprehensive Review. ASIPP Publishing, Paducah, KY, 2011, pp 87-114.

51. Datta S, Everett CR, Trescot AM, Schultz DM, Adlaka R, Abdi S, Atluri SL, Smith HS, Shah RV. An updated systematic review of diagnostic utility of selective nerve root blocks. Pain Physician 2007; 10:113-128.

52. Saal JS. General principles of diagnostic testing as related to painful lumbar spine disorders: A critical appraisal of current diagnostic techniques. Spine (Phila Pa 1976) 2002; 27:2538-2545.

53. Wheeler AH, Murrey DB. Chronic lumbar spine and radicular pain: Pathophysiology and treatment. Curr Pain Headache Rep 2002; 6:97-105.

54. Merskey H, Bogduk N. Classification of Chronic Pain: Descriptions of Chronic Pain Syndromes and Definition of Pain Terms. 2nd ed. Task Force on Taxonomy of the International Association for the Study of Pain. IASP Press, Seattle, 1994.

55. Murphy DR, Hurwitz EL, Gerrard JK, Clary R. Pain patterns and descriptions in patients with radicular pain: Does the pain necessarily follow a specific dermatome? Chiropr Osteopat 2009; 17:9.

56. Schoenfeld AJ, Laughlin M, Bader JO, Bono CM. Characterization of the incidence and risk factors for the development of lumbar radiculopathy. J Spinal Disord Tech 2012; 25:163-167.

57. Heliovaara M, Impivaara O, Sievers $K$, Melkas T, Knekt P, Korpi J, Aromaa A. Lumbar disc syndrome in Finland. Epidemiol Community Health 1987; 41:251258.
58. Bogduk N. Low back pain. In: Clinical Anatomy of Lumbar Spine and Sacrum. Fourth ed. Churchill Livingstone, New York, 2005; pp 183-216.

59. Kelsey JL. Epidemiology of radiculopathies. Adv Neurol 1978; 19:385-398.

6o. Arbit E, Pannullo S. Lumbar stenosis: A clinical review. Clin Orthop 2001; 384:137-143.

61. Katz JN. Lumbar disc disorders and low-back pain: Socioeconomic factors and consequences. J Bone Joint Surg Am 2006; 88:21-24.

62. Shah RV. The problem with diagnostic selective nerve root blocks. Spine (Phila Pa 1976) 2012; 37:1991-1993.

63. Bogduk N. International Spinal Injection Society guidelines for the performance of spinal injection procedures: Part 1: Zygapophysial joint blocks. Clin J Pain 1997; 13:285-302.

64. Bamford G. Popper's explications of ad hocness: Circularity, empirical content, and scientific practice. $\mathrm{Br}$ J Philos Sci 1993; 44:335-355.

65. Simopoulos TT, Manchikanti L, Singh V, Gupta S, Hameed H, Diwan S, Cohen SP. A systematic evaluation of prevalence and diagnostic accuracy of sacroiliac joint interventions. Pain Physician 2012; 15:E305-E344.

66. Manchikanti L, Benyamin RM, Singh V, Falco FJE, Hameed H, Derby R, Wolfer LR, Helm II S, Calodney AK, Datta S, Snook LT, Caraway DL, Hirsch JA, Cohen SP. An update of systematic appraisal of accuracy of utility of lumbar discography in chronic low back pain. Pain Physician 2013;

67. Onyewu O, Manchikanti L, Falco FJE, Singh V, Geffert S, Helm II S, Cohen SP, Hirsch JA. An update of the appraisal of the accuracy and utility of cervical discography in chronic neck pain. Pain Physician 2012; 15:E777-E806.

68. Singh V, Manchikanti L, Onyewu O, Benyamin RM, Datta S, Geffert S, Parr AT, Falco FJE. An update of appraisal of accuracy of thoracic discography as a diagnostic test for chronic spinal pain. Pain Physician 2012; 15:E757-E776.

69. Falco FJE, Manchikanti L, Datta S, Sehgal N, Geffert S, Onyewu O, Singh V, Bryce DA, Benyamin RM, Simopoulos TT, Vallejo R, Gupta S, Ward SP, Hirsch JA. An update of the systematic assessment of the diagnostic accuracy of lumbar facet joint nerve blocks. Pain Physician 2012; 15:E869-E907.

70. Atluri S, Singh V, Datta S, Geffert S, Seh- gal N, Falco FJE. Diagnostic accuracy of thoracic facet joint nerve blocks: An update of the assessment of evidence. Pain Physician 2012; 15:E483-E496.

71. Falco FJE, Datta S, Manchikanti L, Sehgal N, Geffert S, Singh V, Smith HS, Boswell MV. An updated review of diagnostic utility of cervical facet joint injections. Pain Physician 2012; 15:E807-E838.

72. Manchikanti L, Datta S, Derby R, Wolfer LR, Benyamin RM, Hirsch JA. A critical review of the American Pain Society clinical practice guidelines for interventional techniques: Part 1. Diagnostic interventions. Pain Physician 2010; 13:E141E174.

73. Rubinstein SM, van Tulder M. A best-evidence review of diagnostic procedures for neck and low-back pain. Best Pract Res Clin Rheumatol 2008; 22:471-482.

74. Hancock MJ, Maher CG, Latimer J, Spindler MF, McAuley JH, Laslett M, Bogduk N. Systematic review of tests to identify the disc, SIJ or facet joint as the source of low back pain. Eur Spine J 2007; 16:1539-1550.

75. Bogduk N. Lumbar spinal nerve blocks. In: Practice Guidelines for Spinal Diagnostic and Treatment Procedures. 1st edition. International Spine Intervention Society, San Francisco, 2004, pp 3-19.

76. Gajraj NM. Selective nerve root blocks for low back pain and radiculopathy. Reg Anesth Pain Med 2004; 29:243-256.

77. Datta S, Pai U. Selective nerve root block--is the position of the needle transforaminal or paraforaminal? Call for a need to reevaluate the terminology. Reg Anesth Pain Med 2004; 29:616617.

78. Faraj AA, Mulholland RC. The value of nerve root infiltration for leg pain when used with a nerve stimulator. Eur Spine ] 2006; 15:1495-1499.

79. Wolff AP, Groen GJ, Wilder-Smith $\mathrm{OH}$, Richardson J, van Edmond J, Crul BJ. Do diagnostic segmental nerve root blocks in chronic low back pain patients with radiation to the leg lack distinct sensory effects? A preliminary study. $\mathrm{Br}$ ] Anaesth 2006; 96:253-258.

8o. Wolff AP, Groen GJ, Wilder-Smith $\mathrm{OH}$. Influence of needle position on lumbar segmental nerve root block selectivity. Reg Anesth Pain Med 2006; 31:523-530.

81. Vassiliev D. Spread of contrast during $L_{4}$ and $L_{5}$ nerve root infiltration under fluoroscopic guidance. Pain Physician 2007; 10:461-466.

82. Furman MB, Lee TS, Mehta A, Simon Jl, 
Cano WG. Contrast flow selectivity during transforaminal lumbosacral epidural steroid injections. Pain Physician 2008; 11:855-861.

83. Furman MB, Mehta AR, Kim RE, Simon II, Patel R, Lee TS, Reeves RS. Injectate volumes needed to reach specific landmarks in lumbar transforaminal epidural injections. PM R 2010; 2:625-635.

84. Furman MB, Butler SP, Kim RE, Mehta $A R$, Simon JI, Patel R, Lee TS, Reeves RS Injectate volumes needed to reach specific landmarks in S1 transforaminal epidural injections. Pain Med 2012; 13:13651274.

85. Steindler A, Luck JV. Differential diagnosis of pain in the low back: Allocation of the source of the pain by the procaine hydrochloride method. JAMA 1938; 110:106-113.

86. MacNab I. Negative disc exploration: An analysis of the causes of nerve root involvement in sixty-eight patients. ] Bone Joint Surg [AM] 1971; 53A:891-903.

87. Nachemson A. Newest knowledge of low back pain: A critical look. Clin Orthop Rel Res 1992; 279:8-20.

88. Van Akkerveeken PF. The diagnostic value of nerve root sheath infiltration. Acta Orthop Scand Suppl 1993; 251:61-63.

89. Freynhagen R, Baron R, Gockel U, Tölle TR. painDETECT: a new screening questionnaire to identify neuropathic components in patients with back pain. Curr Med Res Opin 2006; 22:1911-1920.

90. El Sissi W, Arnaout A, Chaarani M, Fouad M, El Assuity W, Zalzala M, Dershaby $Y E$, Youseif E. Prevalence of neuropathic pain among patients with chronic lowback pain in the Arabian Gulf Region assessed using the Leeds assessment of neuropathic symptoms and signs pain scale. J Int Med Res 2010; 38:2135-2145.

91. Beith I, Kemp A, Kenyon J, Prout M, Chestnut TJ. Identifying neuropathic back and leg pain: a cross-sectional study. Pain 2011; 152:1511-1516.

92. Kaki A, El-Yaski A, Youseif E. Identifying neuropathic pain among patients with chronic low-back pain: use of the Leeds Assessment of Neuropathic Symptoms and Signs pain scale. Reg Anesth Pain Med 2005; 30:422-428.

93. Hassan A, Saleh H, Baroudy Y, AbdulRahman KI, Najjar MW, Kazi MS, El-Gazar MA, Hafez MA, Abdullah MA, AbdulRahman YA, Youseif EA. Prevalence of neuropathic pain among patients suffering from chronic low back pain in Saudi Arabia. Saudi Med J 2004; 25:19861990.
94. Manninen P, Riihimaki $\mathrm{H}$, Heliovaara $M$. Incidence and risk factors of lowback pain in middle-aged farmers. Occup Med 1995; 45:141-146.

95. Wolff MW, Levine LA. Cervical radiculopathies: Conservative approaches to management. Phys Med Rehabil Clin North Am 2002; 13:589-608.

96. Falco FJE, Manchikanti L, Datta S, Wargo BW, Geffert S, Bryce DA, Atluri S, Singh V, Benyamin RM, Sehgal N, Ward S, Helm II S, Gupta S, Boswell MV. Systematic review of therapeutic effectiveness of cervical facet joint interventions: An update. Pain Physician 2012; 15:E839E868.

97. Manchikanti KN, Atluri S, Singh V, Geffert S, Sehgal N, Falco FJE. An update of evaluation of therapeutic thoracic facet joint interventions. Pain Physician 2012; 15: E463-E481.

98. Hansen H, Manchikanti L, Simopoulous TT, Christo PJ, Gupta S, Smith HS, Hameed $\mathrm{H}$, Cohen SP. A systematic evaluation of the therapeutic effectiveness of sacroiliac joint interventions. Pain Physician 2012; 15:E247-E278.

99. Helm S II, Deer TR, Manchikanti L, Datta S, Chopra P, Singh V, Hirsch JA. Effectiveness of thermal annular procedures in treating discogenic low back pain. Pain Physician 2012; 15:E279-E304.

100. Helm S II, Benyamin RM, Chopra P, Deer TR, Justiz R. Percutaneous adhesiolysis in the management of chronic low back pain in post lumbar surgery syndrome and spinal stenosis: A systematic review. Pain Physician 2012; 15:E435-E462.

101. Falco FJE, Manchikanti L, Datta S, Sehgal N, Geffert S, Onyewu O, Zhu J, Coubarous S, Hameed M, Ward SP, Sharma $M$, Hameed $H$, Singh V, Boswell MV. An update of the effectiveness of therapeutic lumbar facet joint interventions. Pain Physician 2012; 15:E909-E953.

102. Radhakrishnan K, Litchy WJ, O'Fallon WM, Kurland LT. Epidemiology of cervical radiculopathy. A population-based study from Rochester, Minnesota, 1976 through 1990. Brain 1994; 117:325-335.

103. Milette PC. Radiculopathy, radicular pain, radiating pain, referred pain: What are we really talking about? Radiology 1994;192:280-281.

104. Murphy DR. Cervical radiculopathy and pseudoradicular syndromes. In: Murphy DR (ed). Conservative Management of Cervical Spine Syndromes. McGraw-Hill, New York, 2000, pp 189-220.

105. Gifford L. Acute low cervical nerve root conditions symptom presentations and pathobiological reasoning. Man Ther 2001; 6:106-115.

106. Bove GM, Saheen A, Bajwa Z. Subjective nature of lower limb radicular pain. J Manipulative Physiol Ther 2005; 28:1214.

107. Anderberg L, Annertz M, Rydholm U, Brandt L, Saveland H. Selective diagnostic nerve root block for the evaluation of radicular pain in the multileval degenerated cervical spine. Eur Spine J 2006; 15:794-801.

108. Bartynski WS, Kang MD, Rothfus WE. Adjacent double-nerve root contributions in unilateral lumbar radiculopathy. AJNR Am J Neuroradiol 2010; 31:327-333.

109. Riew KD, Yin Y, Gilula L, Bridwell KH, Lenke LG, Lauryssen C, Goette K. The effect of nerve root injections on the need for operative treatment of lumbar radicular pain. J Bone Joint Surg Am 2000; 82A:1589-1593.

110. Kraemer J, Ludwig J, Bickert U, Owczarek V, Traupe M. Lumbar perineural epidural injection: A new technique. Eur Spine J 1997; 6:357-361.

111. Thomas E, Cyteval C, Abiad L, Picot MC, Taourel P, Blotman F. Efficacy of transforaminal versus interspinous corticosteroid injection distal radiculalgia - a prospective, randomized, double-blind study. Clin Rheum 2003; 22:299-304.

112. Karppinen J, Malmivaara A, Kurunlahti M, Kyllonen E, Pienimaki T, Nieminen P, Ohinmaa A, Tervonen O, Vanharanta $H$. Periradicular infiltration for sciatica: A randomized controlled trial. Spine ( $\mathrm{Ph}$ ila Pa 1976) 2001; 26:1059-1067.

113. Vad VB, Bhat AL, Lutz GE, Cammisa F. Transforaminal epidural steroid injections in lumbosacral radiculopathy: $\mathrm{A}$ prospective randomized study. Spine (Phila Pa 1976) 2002; 27:11-15.

114. Lutz GE, Vad VB, Wisneski RJ. Fluoroscopic transforaminal epidural steroid injections: An outcome study. Arch Phys Med Rehabil 1998; 79:1362-1366.

115. Bush K, Hillier S. Outcome of cervical radiculopathy treated with periradicular epidural corticosteroid injections: A prospective study with independent clinical review. Eur Spine J 1996; 5:319-325.

116. Weiner BK, Fraser RD. Foraminal injection for lateral lumbar disc herniation. J Bone Joint Surg Br 1997; 79B:804-807.

117. Karppinen J. Letter in response to periradicular infiltration for sciatica. Spine (Phila Pa 1976) 2002; 27:216-217.

118. Manchikanti L. Transforaminal lumbar 
epidural steroid injections. Pain Physician 2000; 3:374-398.

119. Manchikanti L, Cash KA, Pampati V, Damron KS, McManus CD. Evaluation of lumbar transforaminal epidural injections with needle placement and contrast flow patterns: A prospective, descriptive report. Pain Physician 2004; 7:217-223.

120. Karppinen J, Ohinmaa A, Malmivaara A, Kurunlahti $M$, Kyllonen E, Pienimaki $T$, Nieminen P, Tervonen O, Vanharanta $\mathrm{H}$. Cost effectiveness of periradicular infiltration for sciatica: Subgroup analysis of a randomized controlled trial. Spine (Phila Pa 1976) 2001; 26:2587-2595.

121. Manchikanti L, Singh V. Periradicular infiltration for sciatica. Spine (Phila $\mathrm{Pa}$ 1976) 2002; 27:215-217.

122. Castro $W H$, Gronemeyer D, Jerosch J, Seibel R, Lorenz G, Beutelstahl D, Ohlbrecht K, Gohlke KH. How reliable is lumbar nerve root sheath infiltration? Eur Spine J 1994; 3:255-257.

123. Anderberg L, Saveland H, Annertz M. Distribution patterns of transforaminal injections in the cervical spine evaluated by multi-slice computed tomography. Eur Spine J 2006; 15:1465-1471.

124. Manchikanti L, Malla Y, Wargo BW, Cash KA, Pampati V, Fellows B. A prospective evaluation of complications of 10,000 fluoroscopically directed epidural injections. Pain Physician 2012; 15:131-140.

125. Manchikanti L, Malla Y, Wargo BW, Cash KA, Pampati V, Fellows B. Complications of fluoroscopically directed facet joint nerve blocks: A prospective evaluation of 7,500 episodes with 43,000 nerve blocks. Pain Physician 2012; 15:E143-E150.

126. Tiso RL, Cutler T, Catania JA, Whalen K. Adverse central nervous system sequelae after selective transforaminal block: The role of corticosteroids. Spine J 2004; 4:468-474.

127. Glaser SE, Falco FJE. Paraplegia following a thoracolumbar transforaminal epidural steroid injection. Pain Physician 2005; 8:309-314.

128. Glaser SE, Shah RV. Root cause analysis of paraplegia following transforaminal epidural steroid injections: The "unsafe" triangle. Pain Physician 2010; 13:237-244.

129. Karaman H, Kavak GO, Tüfek A, Yldrm $Z B$. The complications of transforaminal lumbar epidural steroid injections. Spine (Phila Pa 1976) 2011; 36:E819-E824.

130. Goodman BS, Bayazitoglu M, Mallempati S, Noble BR, Geffen JF. Dural puncture and subdural injection: A complica- tion of lumbar transforaminal epidural injections. Pain Physician 2007; 10:697706.

131. Houten JK, Errico TJ. Paraplegia after lumbosacral nerve root block: Report of three cases. Spine ] 2002; 2:70-75.

132. Kim do W, Han KR, Kim C, Chae YJ. Intravascular flow patterns in transforaminal epidural injections: A comparative study of the cervical and lumbar vertebral segments. Anesth Analg 2009; 109:233-239.

133. Birkenmaier C, Baumert S, Schroeder C, Jansson V, Wegener B. A biomechanical evaluation of the epidural neurolysis procedure. Pain Physician 2012; 15:E89E97.

134. Gazelka HM, Burgher AH, Huntoon MA, Mantilla CB, Hoelzer BC. Determination of the particulate size and aggregation of clonidine and corticosteroids for epidural steroid injection. Pain Physician 2012; 15:87-93.

135. Kim H, Choi YL, Lee DK, Choi SS, Lee IO, Kong $\mathrm{MH}$, Kim NS, Lim SH, Lee $M$. The neurological safety of intrathecal acyclovir in rats. Pain Physician 2012; 15:E107-E113.

136. Stauber B, Ma L, Nazari R. Cardiopulmonary arrest following cervical epidural injection. Pain Physician 2012; 15:147152.

137. Kang SS, Hwang BM, Son $H$, Cheong IY, Lee SJ, Chung TY. Changes in bone mineral density in postmenopausal women treated with epidural steroid injections for lower back pain. Pain Physician 2012; 15:229-236.

138. Gomes LM, Garcia JB, Ribamar JS Jr, Nascimento AG. Neurotoxicity of subarachnoid preservative-free $\mathrm{S}(+)$-ketamine in dogs. Pain Physician 2011; 14:83-90.

139. Abdulla S, Abdulla W, Eckhardt R. Caudal normal saline injections for the treatment of post-dural puncture headache. Pain Physician 2011; 14:271-279.

140. Newmark JL, Mehra A, Singla AK. Radiocontrast media allergic reactions and interventional pain practice--a review. Pain Physician 2012; 15:E665-E675.

141. Muir JJ, Pingree MJ, Moeschler SM. Acute cauda equina syndrome secondary to a lumbar synovial cyst. Pain Physician 2012; 15:435-440.

142. Yi Y, Hwang B, Son H, Cheong I. Low bone mineral density, but not epidural steroid injection, is associated with fracture in postmenopausal women with low back pain. Pain Physician 2012;
15:441-449.

143. Chon JY, Moon HS. Salivary cortisol concentration changes after epidural steroid injection. Pain Physician 2012; 15:461-466.

144. Fessler D, Beach J, Keel J, Stead W. latrogenic hypercortisolism complicating triamcinolone acetonide injections in patients with HIV on ritonavir-boosted protease inhibitors. Pain Physician 2012; 15:489-493.

145. Botwin KP, Gruber RD, Bouchlas CG, Torres-Ramos FM, Freeman TL, Slaten WK. Complications of fluoroscopically guided transforaminal lumbar epidural injections. Arch Phys Med Rehabil 2000; 81:1045-1050.

146. Macvicar J, King W, Landers $\mathrm{MH}$, Bogduk N. The effectiveness of lumbar transforaminal injection of steroids: A comprehensive review with systematic analysis of the published data. Pain Med 2013; 14:14-28.

147. Manchikanti L, Malla Y, Wargo BW, Fellows B. Infection control practices (safe injection and medication vial utilization) for interventional techniques: Are they based on relative risk management or evidence? Pain Physician 2011; 14:425434 .

148. Manchikanti L, Falco FJE, Benyamin RM, Caraway DL, Helm II, S, Wargo BW, Hansen H, Parr AT, Singh S, Hirsch JA. Assessment of infection control practices for interventional techniques: A best evidence synthesis of safe injection practices and use of single-dose medication vials. Pain Physician 2012; 15: E573E614.

149. Manchikanti L, Benyamin RM, Swicegood JR, Falco FJE, Datta S, Pampati $\checkmark$, Fellows B, Hirsch JA. Assessment of practice patterns of perioperative management of antiplatelet and anticoagulant therapy in interventional pain management. Pain Physician 2012; 15:E955E968.

150. Lucas NP, Macaskill P, Irwig L, Bogduk $N$. The development of a quality appraisal tool for studies of diagnostic reliability (QAREL). ] Clin Epidemiol 2010; 63:854-861.

151. Lucas N, Macaskill P, Irwig L, Moran R, Bogduk N. Reliability of physical examination for diagnosis of myofascial trigger points: A systematic review of the literature. Clin J Pain 2009; 25:80-89.

152. Manchikanti L, Derby R, Wolfer LR, Singh V, Datta S, Hirsch JA. Evidencebased medicine, systematic reviews, and guidelines in interventional pain man- 
agement: Part 7: Systematic reviews and meta-analyses of diagnostic accuracy studies. Pain Physician 2009; 12:929-963.

153. Bossuyt PM, Reitsma JB, Bruns DE, Gatsonis CA, Glasziou PP, Irwig LM, Lijmer JG, Moher D, Rennie D, de Vet HC; STARD Group. Towards complete and accurate reporting of studies of diagnostic accuracy: The STARD Initiative. Ann Intern Med 2003; 138:40-44.

154. Whiting $P$, Rutjes AW, Reitsma JB, Bossuyt PM, Kleijnen J. The development of QUADAS: A tool for the quality assessment of studies of diagnostic accuracy included in systematic reviews. BMC Med Res Methodol 2003; 3:25.

155. Liberati A, Altman DG, Tetzlaff J, Mulrow C, Gøtzsche PC, loannidis JP, Clarke M, Devereaux PJ, Kleijnen J, Moher D. The PRISMA statement for reporting systematic reviews and meta-analyses of studies that evaluate health care interventions: Explanation and elaboration. Ann Intern Med 2009; 151:W65-W94.

156. Whiting PF, Rutjes AW, Westwood ME, Mallett S, Deeks JJ, Reitsma JB, Leeflang MM, Sterne JA, Bossuyt PM; QUADAS-2 Group. QUADAS-2: A revised tool for the quality assessment of diagnostic accuracy studies. Ann Intern Med 2011; 155:529536.

157. Gemmell H, Miller P. Interexaminer reliability of multidimensional examination regimens used for detecting spinal manipulable lesions: A systematic review. Clin Chiropractic 2005; 8:199-204.

158. Hestboek L, Leboeuf-Yde C. Are chiropractic tests for the lumbo-pelvic spine reliable and valid? A systematic critical literature review. J Manipulative Physiol Ther 2000; 23:258-275.

159. Hollerwoger D. Methodological quality and outcomes of studies addressing manual cervical spine examinations: A review. Man Ther 2006; 11:93-98.

160. May S, Littlewook C, Bishop A. Reliability of procedures used in the physical examination of non-specific low back pain: A systematic review. Aust J Physiother 2006; 52:91-102.

161. Stochkendahl MJ, Christensen HW, Hartvigsen J, Vach W, Haas M, Hestbaek L, Adams A, Bronfort G. Manual examination of the spine: $A$ systematic critical literature review of reproducibility.] Manipulative Physiol Ther 2006; 29:475-485, 485.e1-10.

162. van Trijffel E, Anderegg Q, Bossuyt PM, Lucas C. Inter-examiner reliability of passive assessment of intervertebral motion in the cervical and lum- bar spine: A systematic review. Man Ther 2005; 10:256-269.

163. van Tulder M, Furlan A, Bombardier C, Bouter L; Editorial Board of the Cochrane Collaboration Back Review Group. Updated method guidelines for systematic reviews in the Cochrane Collaboration Back Review Group. Spine (Phila Pa 1976) 2003; 28:1290-1299.

164. Staal JB, de Bie R, de Vet HC, Hildebrandt J, Nelemans P. Injection therapy for subacute and chronic low-back pain. Cochrane Database Syst Rev 2008; 3:CDool824.

165. Harbord R, Higgins J. METAREG: Stata module to perform meta-analysis regression. Boston College Department of Economics, Boston, MA. http://econpapers.repec.org/software/bocbocode/ s446201.htm

166. Harris RP, Helfand M, Woolf SH, Lohr KN, Mulrow CD, Teutsch SM, Atkins D; Methods Work Group, Third US Preventive Services Task Force. Current methods of the US Preventive Services Task Force. Am J Prevent Med 2001; 20:21-35.

167. Chou R, Huffman L. Use of Chronic Opioid Therapy in Chronic Noncancer Pain: Evidence Review. American Pain Society; Glenview, IL: 2009.

www.americanpainsociety.org/uploads/pdfs/ Opioid_Final_Evidence_Report.pdf

168. Hoppenstein R. A new approach to the failed back syndrome. Spine (Phila Pa 1976) 1980; 5:371-379.

169. Krempen JF, Smith BS. Nerve root injection: A method for evaluating the etiology of sciatica. J Bone Joint Surg Am 1974; 56A:1435-1444.

170. Tajima T, Furukawa K, Kuramochi E. Selective lumbosacral radiculography and block. Spine (Phila Pa 1976) 1980; 1:68-77.

171. Haueisen DC, Smith BS, Myers SR, Pryce ML. The diagnostic accuracy of spinal nerve injection studies. Clin Orthop Rel Res 1985; 198:179-183.

172. Castro WH, van Akkerveeken PF. The diagnostic value of selective lumbar nerve root block. Z Orthop Ihre Grenzgeb 1991; 129:374-379.

173. Kikuchi S, Hasue M, Nishiyama K. Anatomic and clinical studies of radicular symptoms. Spine (Phila Pa 1976) 1984; 9:23-30.

174. Herron LD. Selective nerve root block in patient selection for lumbar surgery: Surgical results. J Spinal Disord 1989; 2:75-79.

175. Yeom JS, Lee JW, Park KW, Chang BS, Lee CK, Buchowski JM, Riew KD. Val- ue of diagnostic lumbar selective nerve root block: A prospective controlled study. AJNR Am J Neuroradiol 2008; 29:1017-1023.

176. Pfirrmann CW, Oberholzer PA, Zanetti M, Boos N, Trudell DJ, Resnick D, Hodler J. Selective nerve root blocks for the treatment of sciatica: Evaluation of injection site and effectiveness--a study with patients and cadavers. Radiology 2001; 221:704-711.

177. Wagner AL. Selective lumbar nerve root blocks with $\mathrm{CT}$ fluoroscopic guidance: Technique, results, procedure time, and radiation dose. AJNR Am J Neuroradiol 2004; 25:1592-1594.

178. Kim C, Choi HE, Kang S. Contrast spreading patterns in retrodiscal transforaminal epidural steroid injection. Ann Rehabil Med 2012; 36:474-479.

179. Miyakoshi N, Shimada $Y$, Kasukawa $Y$, Saito H, Kodama H, Itoi E. Total dorsal ramus block for the treatment of chronic low back pain: A preliminary study. Joint Bone Spine 2007; 74:270-274.

180. Chua NH, Vissers KC, Arendt-Nielsen L, Wilder-Smith $\mathrm{OH}$. Do diagnostic blocks have beneficial effects on pain processing? Reg Anesth Pain Med 2011; 36:317321.

181. Slipman CW, Plastaras CT, Palmitier RA, Huston CW, Sterenfeld EB. Symptom provocation of fluoroscopically guided cervical nerve root stimulation: Are dynatomal maps identical to dermatomal maps? Spine (Phila Pa 1976) 1998; 23:2235-2242.

182. Wolff AP, Groen GJ, Crul BJ. Diagnostic lumbosacral segmental nerve blocks with local anesthetics: A prospective double-blind study on the variability and interpretation of segmental effects. Reg Anesth Pain Med 2001; 26:147-155.

183. Stanley D, McLaren MI, Euinton HA, Getty CJ. A prospective study of nerve root infiltration in the diagnosis of sciatica: A comparison with radiculography, computed tomography, and operative findings. Spine (Phila Pa 1976) 1990; 6:540-543.

184. Anderberg L, Annertz M, Brandt L, Saveland $\mathrm{H}$. Selective diagnostic cervical nerve root block - correlation with clinical symptoms and MRI-pathology. Acta Neurochir 2004; 146:559-565.

185. Dooley JF, McBroom RJ, Taguchi T, MacNab I. Nerve root infiltration in the diagnosis of radicular pain. Spine (Phila Pa 1976) 1988; 13:79-83.

186. Schutz H, Lougheed WM, Wortzman G, Awerbuck BG. Intervertebral nerve-root 
in the investigation of chronic lumbar disc disease. Can J Surg 1973; 16:217-221.

187. Sasso RC, Macadaeg K, Nordmann D, Smith $M$. Selective nerve root injections can predict surgical outcome for lumbar and cervical radiculopathy: Comparison to magnetic resonance imaging.] Spinal Disord Tech 2005; 18:471-478.

188. Porter DG, Valentine AR, Bradford R. A retrospective study to assess the results of CT-directed peri-neural root infiltration in a cohort of 56 patients with low back pain and sciatica. $\mathrm{Br} J$ Neurosurg 1999; 13:290-293.

189. MacMahon PJ, Crosbie I, Kavanagh EC. Reducing the risk of spinal cord infarction during transforaminal steroid injections. AJNR Am J Neuroradiol 2010; 31:E32.

190. Kennedy DJ, Dreyfuss P, Aprill CN, Bogduk N. Paraplegia following imageguided transforaminal lumbar spine epidural steroid injection: Two case reports. Pain Med 2009; 10:1389-1394.

191. Akkaya T, Sayin M. Transforaminal epidural steroid injection and its complications. Agri 2005; 17:27-39.

192. Lyders EM, Morris PP. A case of spinal cord infarction following lumbar transforaminal epidural steroid injection: MR imaging and angiographic findings. AJNR Am J Neuroradiol 2009; 30:16911693 .

193. Scanlon GC, Moeller-Bertram T, Romanowsky SM, Wallace MS. Cervical transforaminal epidural steroid injections. More dangerous than we think? Spine (Phila Pa 1976) 2007; 32:1249-1256.

194. Malhotra G, Abbasi A, Rhee M. Complications of transforaminal cervical epidural steroid injections. Spine (Phila Pa 1976) 2009; 34:731-739.

195. Huntoon MA, Martin DP. Paralysis after transforaminal epidural injection and previous spinal surgery. Reg Anesth Pain Med 2004; 29:494-495.

196. Furman MB, O'Brien EM, Zgleszewski TM. Incidence of intravascular penetration in transforaminal lumbosacral epidural steroid injections. Spine (Phila Pa 1976) 2000; 25:2628-2632.

197. Huston CW, Slipman CW, Garvin C. Complications and side effects of cervical and lumbosacral selective nerve root injections. Arch Phys Med Rehabil 2005: 86:277-283.

198. Manchikanti L, Singh V. Corticosteroids. In: Manchikanti L, Christo PJ, Trescot AM, Falco FJE (eds). Foundations of Pain Medicine and Interventional Pain Management: A Comprehensive Review. ASIPP
Publishing, Paducah, KY, 2011, pp 589606.

199. Sandberg DI, Lavyne MH. Symptomatic spinal epidural lipomatosis after local epidural corticosteroid injections: Case report. Neurosurgery 1999; 45:162-165.

200. Hoang JK, Yoshizumi TT, Toncheva G, Gray L, Gafton AR, Huh BK, Eastwood JD, Lascola CD, Hurwitz LM. Radiation dose exposure for lumbar spine epidural steroid injections: A comparison of conventional fluoroscopy data and CT fluoroscopy techniques. AJR Am J Roentgenol 2011; 197:778-782.

201. Paidin M, Hansen P, McFadden M, Kendall R. Contrast dispersal patterns as a predictor of clinical outcome with transforaminal epidural steroid injection for lumbar radiculopathy. PM $R$ 2011; 3:1022-1027.

202. Plastaras CT, Casey E, Goodman BS, Chou L, Roth D, Rittenberg J. Inadvertent intradiscal contrast flow during lumbar transforaminal epidural steroid injections: A case series examining the prevalence of intradiscal injection as well as potential associated factors and adverse events. Pain Med 2010; 11:17651773.

203. Lee $M H$, Yang KS, Kim YH, Jung HD, Lim SJ, Moon DE. Accuracy of live fluoroscopy to detect intravascular injection during lumbar transforaminal epidural injections. Korean J Pain 2010; 23:18-23.

204. Kim CH, Issa MA, Vaglienti RM. Flushing following interlaminar lumbar epidural steroid injection with dexamethasone. Pain Physician 2010; 13:481-484.

205. Manchikanti L, Cash KA, Moss TL, Pampati $V$. Effectiveness of protective measures in reducing risk of radiation exposure in interventional pain management: A prospective evaluation. Pain Physician 2003; 6:301-305

206. Kabbara A, Rosenberg SK, Untal C. Methicillin-resistant Staphylococcus aureus epidural abscess after transforaminal epidural steroid injection. Pain Physician 2004; 7:269-272.

207. Goodman BS, Posecion LWF, Mallempati S, Bayazitoglu M. Complications and pitfalls of lumbar interlaminar and transforaminal epidural injections. Curr Rev Musculoskelet Med 2008; 1:212-222.

208. McGrath JM, Schaefer MP, Malkamaki DM. Incidence and characteristics of complications from epidural steroid injections. Pain Med 2011; 12:726-731.

209. Eckel TS, Bartynski WS. Epidural steroid injections and selective nerve root blocks. Tech Vasc Interv Radiol 2009; 12:11-21.

210. Manchikanti L, Cash KA, Moss TL, Rivera JJ, Pampati V. Risk of whole body radiation exposure and protective measures in fluoroscopically guided interventional techniques: A prospective evaluation. BMC Anesthesiol 2003; 3:2.

211. Hollmann MW, Durieux M. Local anesthetics and the inflammatory response. Anesthesiology 2000; 93:858-875.

212. Furman MB, O'Brien EM. Is it really possible to do a selective nerve root block? Pain 2000; 85:526.

213. Slosar PJ Jr, White AH, Wetzel FT. Controversy. The use of selective nerve root blocks: Diagnostic, therapeutic, or placebo? Spine (Phila Pa 1976) 1998; 23:22532256.

214. North RB, Kidd DH, Campbell JN, Long DM. Dorsal root ganglionectomy for failed back surgery syndrome: $A$ 5-year follow-up study. J Neurosurg 1991; 74:236-242.

215. North RB, Kidd DH, Zahurak M, Piantadosi S. Specificity of diagnostic nerve blocks: A prospective, randomized study of sciatica due to lumbosacral spine disease. Pain 1996; 65:77-85.

216. Cook DJ, Greengold NL, Ellrodt AG, Weingarten SR. The relation between systematic reviews and practice guidelines. Ann Intern Med 1997; 127:210-216.

217. Cook DJ, Mulrow CD, Haynes RB. Systematic reviews: Synthesis of best evidence for clinical decisions. Ann Intern Med 1997; 126:376-380.

218. Manchikanti L, Singh V, Falco FJ, Cash KA, Pampati V. Evaluation of lumbar facet joint nerve blocks in managing chronic low back pain: A randomized, doubleblind, controlled trial with a 2-year follow-up. Int J Med Sci 2010; 7:124-135.

219. Schwarzer AC, Derby R, Aprill CN, Fortin J, Kine G, Bogduk N. The value of the provocation response in lumbar zygapophyseal joint injections. Clin J Pain 1994; 10:309-313.

220. Destouet JM, Gilula LA, Murphy WA, Monsees B. Lumbar facet joint injection: Indication, technique, clinical correlation, and preliminary results. Radiology 1982; 145:321-325.

221. Lewinnek GE, Warfield CA. Facet joint degeneration as a cause of low back pain. Clin Orthop Relat Res 1986; 213:216222.

222. Carrera GF, Williams AL. Current concepts in evaluation of the lumbar facet joints. Crit Rev Diagn Imaging 1984; 
21:85-104.

223. Eden J, Wheatley B, McNeil B, Sox H. Developing trusted clinical practice guidelines. In: Knowing What Works in Health Care: A Roadmap for the Nation. National Academies Press, Washington, DC, 2008, pp 121-152.

224. Institute of Medicine (IOM). Finding What Works in Health Care: Standards for Systematic Reviews. The National Academies Press, Washington, DC, March 23, 2011.

225. Field MJ, Lohr KN, eds. Clinical Practice Guidelines: Directions for a New Program. Institute of Medicine, National Academy Press, Washington, DC, 1990.

226. Manchikanti L, Singh V, Caraway DL, Benyamin RM, Hirsch JA. Medicare physician payment systems: Impact of 2011 schedule on interventional pain management. Pain Physician 2011; 14:E5-E33.

227. Manchikanti L, Singh V, Datta S, Cohen SP, Hirsch JA. Comprehensive review of epidemiology, scope, and impact of spinal pain. Pain Physician 2009; 12:E35E7o.

228. Schultz DM, Zhou X, Singal A, Musley S. Cardiovascular effects of spinal cord stimulation in hypertensive patients. Pain Physician 2011; 14:1-14.

229. Raffaeli W, Sarti D, Demartini L, Sotgiu A, Bonezzi C; Italian Ziconotide Group. Italian registry on long-term intrathecal ziconotide treatment. Pain Physician 2011; 14:15-24.

230. Gentile DA, Woodhouse J, Lynch P, Maier J, McJunkin T. Reliability and validity of the Global Pain Scale with chronic pain sufferers. Pain Physician 2011; 14:6170.

231. Zhu J, Falco F, Onyewu CO, Joesphson $Y$, Vesga R, Jari R. Alternative approach to needle placement in spinal cord stimulator trial/implantation. Pain Physician 2011; 14:45-53.

232. Korkmazsky M, Ghandehari J, Sanchez A, Lin HM, Pappagallo M. Feasibility study of rapid opioid rotation and titration. Pain Physician 2011; 14:71-82.

233. Manchikanti L, Ailinani H, Koyyalagunta D, Datta S, Singh V, Eriator I, Sehgal N, Shah RV, Benyamin RM, Vallejo R, Fellows B, Christo PJ. A systematic review of randomized trials of long-term opioid management for chronic non-cancer pain. Pain Physician 2011; 14:91-121.

234. Colson J, Koyyalagunta D, Falco FJE, Manchikanti L. A systematic review of observational studies on the effectiveness of opioid therapy for cancer pain.
Pain Physician 2011; 14:E85-E102.

235. Manchikanti L, Singh V, Caraway DL, Benyamin RM. Breakthrough pain in chronic non-cancer pain: Fact, fiction, or abuse. Pain Physician 2011; 14:E103E117.

236. Christo PJ, Manchikanti L, Ruan X, Bottros $M$, Hansen $H$, Solanki D, Jordan $A E$, Colson J. Urine drug testing in chronic pain. Pain Physician 2011; 14:123-143.

237. Solanki DR, Koyyalagunta D, Shah RV, Silverman SM, Manchikanti L. Monitoring opioid adherence in chronic pain patients: Assessment of risk of substance misuse. Pain Physician 2011; 14:E119-E131.

238. Lee $M$, Silverman $S M$, Hansen $\mathrm{H}, \mathrm{Pa}$ tel VB, Manchikanti L. A comprehensive review of opioid-induced hyperalgesia. Pain Physician 2011; 14:145-161.

239. Manchikanti L, Vallejo R, Manchikanti KN, Benyamin RM, Datta S, Christo PJ. Effectiveness of long-term opioid therapy for chronic non-cancer pain. Pain Physician 2011; 14:E133-E156.

240. Manchikanti L, Parr AT, Singh V, Fellows B. Ambulatory surgery centers and interventional techniques: A look at long-term survival. Pain Physician 2011; 14:E177-E215.

241. Manchikanti L, Malla Y, Wargo BW, Fellows B. Comparative evaluation of the accuracy of immunoassay with liquid chromatography tandem mass spectrometry (LC/MS/MS) of urine drug testing (UDT) opioids and illicit drugs in chronic pain patients. Pain Physician 2011; 14:175-187.

242. Pesce A, West C, Rosenthal M, Mikel C, West R, Crews B, Almazan P, Latyshev $S$, Horn PS. Illicit drug use in the pain patient population decreases with continued drug testing. Pain Physician 2011; 14:189-193.

243. Smith HS, Harris R, Clauw D. Fibromyalgia: An afferent processing disorder leading to a complex pain generalized syndrome. Pain Physician 2011; 14:E217E245.

244. Manchikanti L, Falco FJ, Benyamin RM, Helm S 2nd, Parr AT, Hirsch JA. The impact of comparative effectiveness research on interventional pain management: Evolution from Medicare Modernization Act to Patient Protection and Affordable Care Act and the PatientCentered Outcomes Research Institute. Pain Physician 2011; 14:E249-E282.

245. Deer TR, Smith HS, Burton AW, Pope JE, Doleys DM, Levy RM, Staats PS, Wal- lace MS, Webster LR, Rauck RL, Cousins M. Comprehensive consensus based guidelines on intrathecal drug delivery systems in the treatment of pain caused by cancer pain. Pain Physician 2011; 14:E283-E312.

246. Hayek SM, Deer TR, Pope JE, Panchal S), Patel VB. Intrathecal therapy for cancer and non-cancer pain. Pain Physician 2011; 14:219-248.

247. Sehgal N, Smith HS, Manchikanti L. Peripherally acting opioids and clinical implications for pain control. Pain Physician 2011; 14:249-258.

248. Manchikanti L, Malla Y, Wargo BW, Fellows B. Comparative evaluation of the accuracy of benzodiazepine testing in chronic pain patients utilizing immunoassay with liquid chromatography tandem mass spectrometry (LC/MS/MS) of urine drug testing. Pain Physician 2011; 14:259-270.

249. Gupta S. Double needle technique: An alternative method for performing difficult sacroiliac joint injections. Pain Physician 2011; 14:281-284.

250. Hegarty D, Goroszeniuk T. Peripheral nerve stimulation of the thoracic paravertebral plexus for chronic neuropathic pain. Pain Physician 2011; 14:295-300.

251. Kharkar S, Ambady P, Yedatore V, Schwartzman RJ. Intramuscular botulinum toxin $\mathrm{A}$ (BtxA) in complex regional pain syndrome. Pain Physician 2011; 14:311-316.

252. Manchikanti L, Falco FJE, Singh V, Benyamin RM, Hirsch JA. The Independent Payment Advisory Board. Pain Physician 2011; 14:E313-E342.

253. Koyyalagunta D, Burton AW, Toro MP, Driver L, Novy DM. Opioid abuse in cancer pain: Report of two cases and presentation of an algorithm of multidisciplinary care. Pain Physician 2011; 14:E361-E371.

254. Manchikanti L, Malla Y, Wargo BW, Cash KA, McManus CD, Damron KS, Jackson SD, Pampati V, Fellows B. A prospective evaluation of bleeding risk of interventional techniques in chronic pain. Pain Physician 2011; 14:317-329.

255. Grider JS, Harned ME, Etscheidt MA. Patient selection and outcomes using a low-dose intrathecal opioid trialing method for chronic nonmalignant pain. Pain Physician 2011; 14:343-351.

256. Nagda JV, Davis CW, Bajwa ZH, Simopoulos TT. Retrospective review of the efficacy and safety of repeated pulsed and continuous radiofrequency lesioning of the dorsal root ganglion/segmen- 
tal nerve for lumbar radicular pain. Pain Physician 2011; 14:371-376.

257. Smith $H$. Painful osseous metastases (POM). Pain Physician 2011; 14:E373E403.

258. Gupta A, Patton C, Diskina D, Cheatle M. Retrospective review of physician opioid prescribing practices in patients with aberrant behaviors. Pain Physician 2011; 14:383-389.

259. Schade CM, Schultz DM, Tamayo N, lyer S, Panken E. Automatic adaptation of neurostimulation therapy in response to changes in patient position: Results of the Posture Responsive Spinal Cord Stimulation (PRS) Research Study. Pain Physician 2011; 14:407-417.

260. Kharkar S, Ambady P, Venkatesh Y, Schwartzman RJ. Intramuscular botulinum toxin in complex regional pain syndrome: Case series and literature review. Pain Physician 2011; 14:419-424.

261. Hirsch AE, Jha RM, Yoo AJ, Saxena A, Ozonoff A, Growney MJ, Hirsch JA. The use of vertebral augmentation and external beam radiation therapy in the multimodal management of malignant vertebral compression fractures. Pain Physician 2011; 14:447-458.

262. Harmon D, Alexiev V. Sonoanatomy and injection technique of the iliolumbar ligament. Pain Physician 2011; 14:469474.
263. Harned ME, Salles SS, Grider JS. An introduction to trialing intrathecal baclofen in patients with hemiparetic spasticity: A description of 3 cases. Pain Physician 2011; 14:483-489.

264. Smith HS. Painful rheumatoid arthritis. Pain Physician 2011; 14:E427-E458.

265. Grothusen JR, Schwartzman RJ. Laser Doppler imaging: Usefulness in chronic pain medicine. Pain Physician 2011; 14:491-498.

266. Kim DD, Vakharyia R, Kroll HR, Shuster $A$. Rates of lead migration and stimulation loss in spinal cord stimulation: A retrospective comparison of laminotomy versus percutaneous implantation. Pain Physician 2011; 14:513-524.

267. Kim CH, Issa MA, Vaglienti RM. Use of observational mechanical gateway connector in spinal cord stimulation trials. Pain Physician 2011; 14:525-530.

268. Lim BG, Lee JY, Lee MK, Lee DK, Kim JS, Choi SS. Kyphoplasty for the treatment of vertebral compression fractures in a cancer patient with neurological deficits and anterior vertebral wall destruction. Pain Physician 2011; 14:539-544.

269. Bokov A, Istrelov A, Skorodumov A, Aleynik A, Simonov A, Mlyavykh S. An analysis of reasons for failed back surgery syndrome and partial results after different types of surgical lumbar nerve root decompression. Pain Physician 2011; 14:545-557.

270. Boogaard S, Heymans MW, Patijn J, de Vet HC, Faber CG, Peters ML, Loer SA, Zuurmond WW, Perez R. Predictors for persistent neuropathic pain--a Delphi survey. Pain Physician 2011; 14:559-568.

271. Kadish L, Simmons E. Anomalies of the lumbosacral nerve roots. An anatomical investigation and myelographic study. J Bone Joint Surg $\mathrm{Br}$ 1984; 66:411-416.

272. Kikuchi S, Hause M, Nishiyama K, Ito T. Anatomic features of the furcal nerve and its clinical significance. Spine (Phila $\mathrm{Pa}$ 1976) 1986; 11:1002-1007.

273. Xavier A, Farrell C, McDanal J, Kissin I. Does antidromic activation of nociceptors play a role in sciatic radicular pain? Pain 1990; 40:77-79.

274. Kissin I, Xavier A, McDanal J. Blockade of sciatic nerve branches relieves sciatic radicular pain. Anesth Analg 1989; 69:262-263.

275. Hockaday J, Whitty C. Patterns of referred pain in the normal subject. Brain 1967; 90:481-496.

276. Beecher $\mathrm{H}$. The powerful placebo. JAMA 1955; 159:1602-1606.

277. Turner J, Deyo R, Loeser J, Von Korff M, Fordyce W. The importance of placebo effects in pain treatment and research. JAMA 1994; 271:1609-1614. 